\title{
Identification and Characterization of $\mathrm{GABA}_{\mathrm{A}}$ Receptor Autoantibodies in Autoimmune Encephalitis
}

\author{
Toshika Ohkawa, ${ }^{1,3}$ Shin'Ichiro Satake, ${ }^{2,3}$ Norihiko Yokoi, ${ }^{1,3}$ Yu Miyazaki, ${ }^{4}$ Tomohiko Ohshita,,${ }^{5}$ Gen Sobue, ${ }^{4}$ \\ Hiroshi Takashima, ${ }^{6}$ Osamu Watanabe, ${ }^{6}$ Yuko Fukata, ${ }^{1,3 *}$ and Masaki Fukata ${ }^{1,3 *}$ \\ ${ }^{1}$ Division of Membrane Physiology, Department of Cell Physiology, and 2Division of Neural Signaling, Department of Information Physiology, National \\ Institute for Physiological Sciences, National Institutes of Natural Sciences; and ${ }^{3}$ Department of Physiological Sciences, School of Life Science, The Graduate \\ University for Advanced Studies (SOKENDAI), Okazaki 444-8787, Japan; ${ }^{4}$ Department of Neurology, Nagoya University Graduate School of Medicine, \\ Nagoya 466-8550, Japan; 5Department of Neurology, Suiseikai Kajikawa Hospital, Hiroshima 730-0046, Japan; and ${ }^{6}$ Department of Neurology and \\ Geriatrics, Kagoshima University Graduate School of Medical and Dental Sciences, Kagoshima 890-8544, Japan
}

Autoimmune forms of encephalitis have been associated with autoantibodies against synaptic cell surface antigens such as NMDA- and AMPA-type glutamate receptors, $\mathrm{GABA}_{\mathrm{B}}$ receptor, and LGI1. However, it remains unclear how many synaptic autoantigens are yet to be defined. Using immunoproteomics, we identified autoantibodies against the $\mathrm{GABA}_{\mathrm{A}}$ receptor in human sera from two patients diagnosed with encephalitis who presented with cognitive impairment and multifocal brain MRI abnormalities. Both patients had antibodies directed against the extracellular epitope of the $\beta 3$ subunit of the $\mathrm{GABA}_{\mathrm{A}}$ receptor. The $\beta 3$-subunit-containing $\mathrm{GABA}_{\mathrm{A}}$ receptor was a major target of the patients' serum antibodies in rat hippocampal neurons because the serum reactivity to the neuronal surface was greatly decreased by $80 \%$ when the $\beta 3$ subunit was knocked down. Our developed multiplex ELISA testing showed that both patients had similar levels of $\mathrm{GABA}_{\mathrm{A}}$ receptor antibodies, one patient also had a low level of LGI1 antibodies, and the other also had CASPR2 antibodies. Application of the patients' serum at the time of symptom presentation of encephalitis to rat hippocampal neuron cultures specifically decreased both synaptic and surface $\mathrm{GABA}_{\mathrm{A}}$ receptors. Furthermore, treatment of neurons with the patients' serum selectively reduced miniature IPSC amplitude and frequency without affecting miniature EPSCs. These results strongly suggest that the patients' GABA

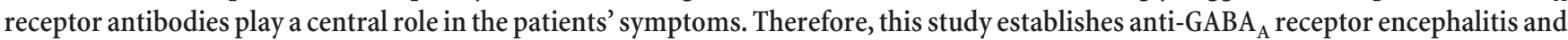
expands the pathogenic roles of $\mathrm{GABA}_{\mathrm{A}}$ receptor autoantibodies.

Key words: autoantibody; autoimmune encephalitis; cognitive impairment; $\mathrm{GABA}_{\mathrm{A}}$ receptor; seizure; thymoma

\section{Introduction}

Autoimmune neurological disorders are induced through the production of autoantibodies. Identifying the target antigens and elucidating the pathogenic mechanisms of autoantibodies play extremely important roles in the diagnosis and treatment of autoimmune disorders (Vincent et al., 2006; Moscato et al., 2010;

\footnotetext{
Received Oct. 15, 2013; revised April 25, 2014; accepted May 5, 2014.

Author contributions: T. Ohkawa, Y.F., and M.F. designed research; T. Ohkawa, S.S., Y.F., and M.F. performed research; N.Y., Y.M., T. Ohshita, G.S., H.T., O.W., Y.F., and M.F. contributed unpublished reagents/analytic tools; T. Ohkawa, S.S., O.W., Y.F., and M.F. analyzed data; T. Ohkawa, Y.F., and M.F. wrote the paper.

This work was supported by the Ministry of Education, Culture, Sports, Science and Technology (Grant 25110733 to Y.F. and Grant 25461286 to 0.W.); the Ministry of Health, Labour and Welfare (Intramural Research Grant H24-12 for Neurological and Psychiatric Disorders of NCNP to Y.F., Grant 24133701, and Research on Measures for Intractable Diseases Grant H24-017 to 0.W.); and the Cabinet Office (Funding Program for Next Generation World-Leading Researchers Grant LS123 to M.F.). We thank K. Imoto and H. Furue for encouragement and helpful suggestions; B. Lüscher for a plasmid encoding $\mathrm{GABA}_{\mathrm{A}}$ receptor $\gamma 2$; the members of the Fukata and Takashima laboratories, $\mathrm{Y}$. Shirahama, T. Kohriyama, and K. Ochi for kind support; all of the physicians who provided serum samples and clinical information from the patients; and all of the patients and their families.

The authors declare no competing financial interests.

Correspondence should be addressed to either Yuko Fukata or Masaki Fukata, Division of Membrane Physiology, Department of Cell Physiology, National Institute for Physiological Sciences, National Institutes of Natural Sciences, 5-1 Higashiyama, Myodaiji, 0kazaki, Aichi 444-8787, Japan, E-mail: yfukata@nips.ac.jp or mfukata@nips.ac.jp.

*Y.F. and M.F. contributed equally to this work.

DOI:10.1523/JNEUROSCI.4415-13.2014

Copyright $\odot 2014$ the authors $\quad 0270-6474 / 14 / 348151-13 \$ 15.00 / 0$
}

Lancaster and Dalmau, 2012). In particular, autoantibodies to synaptic cell surface antigens have attracted considerable attention because such antibodies may be directly pathogenic by interfering with synaptic functional proteins.

In the CNS, antibodies to the metabotropic glutamate receptor 1, which cause cerebellar ataxia, were found in two patients with Hodgkin's disease (Sillevis Smitt et al., 2000). Antibodies to the ionotropic NMDA-type glutamate receptor were then identified in many patients with ovarian tumors, psychiatric symptoms, amnesia, seizures, and impaired consciousness (Dalmau et al., 2007). This disease has since been established as "anti-NMDA receptor encephalitis” (Dalmau et al., 2008). Since 2009, immunoprecipitation coupled with mass spectrometry analysis using patient serum antibodies has accelerated the identification of target antigens associated with limbic encephalitis characterized by subacute onset of amnesia and seizures. Another major ionotropic glutamate receptor, the AMPA receptor (Lai et al., 2009), the inhibitory metabotropic $\mathrm{GABA}_{\mathrm{B}}$ receptor (Lancaster et al., 2010), and CASPR2 and LGI1, which were previously recognized as the voltage-gated potassium channel (VGKC) (Irani et al., 2010; Lai et al., 2010), were identified as cell surface autoantigens in patients with limbic encephalitis. In addition, antibodies to inhibitory ionotropic glycine receptor were reported in a spec- 
trum of brainstem and spinal hyperexcitability disorders (stiffperson syndrome phenotype) (Hutchinson et al., 2008; McKeon et al., 2013).

The ionotropic $\mathrm{GABA}_{\mathrm{A}}$ receptor mediates most of the fast inhibitory synaptic transmission in the brain and is composed of heteropentameric assemblies of different subunit subtypes $[\alpha(1-$ 6), $\beta$ (1-3), $\gamma(1-3), \delta, \varepsilon, \theta, \pi$, and $\rho(1-3)]$ to form chloride ion channels (Macdonald and Olsen, 1994; Jacob et al., 2008; Rudolph and Knoflach, 2011). The majority of $\mathrm{GABA}_{\mathrm{A}}$ receptors contain two $\alpha$ subunits, two $\beta$ subunits, and one $\gamma$ or $\delta$ subunit. The $\mathrm{GABA}_{\mathrm{A}}$ receptor plays a central role in the regulation of brain excitability and is targeted by many antiepileptic, sedative, and anxiolytic drugs, including benzodiazepines and barbiturates. In addition, mutations in human $\mathrm{GABA}_{\mathrm{A}}$ receptor subunits, including $\alpha 1, \beta 3, \gamma 2$, and $\delta$, cause genetic epilepsy syndromes (Macdonald et al., 2010) and genetic loss of the $\beta 3$ subunit in mice causes seizures and learning and memory deficits (DeLorey et al., 1998). Therefore, although the $\mathrm{GABA}_{\mathrm{A}}$ receptor can be a strong candidate affected in autoimmune CNS disorders, $\mathrm{GABA}_{\mathrm{A}}$ receptor antibodies have not yet been reported.

Here, using a nonbiased proteomic method, we identified autoantibodies against the $\mathrm{GABA}_{\mathrm{A}}$ receptor in two patients with encephalitis. The patients' $\mathrm{GABA}_{\mathrm{A}}$ receptor antibodies specifically caused downregulation of $\mathrm{GABA}_{\mathrm{A}}$ receptors. The present study establishes a pathogenic role of $\mathrm{GABA}_{\mathrm{A}}$ receptor antibodies in certain cases of encephalitis.

\section{Materials and Methods}

Experiments. The experiments using human sera were reviewed and approved by ethic committees at the National Institute for Physiological Sciences (NIPS), Nagoya University, and Kagoshima University, and written informed consent was obtained from all patients or their family members. All animal studies were reviewed and approved by the ethic committees at NIPS and were performed according to the institutional guidelines concerning the care and handling of experimental animals.

Study population and serum samples. We collected $\sim 1200$ serum samples from patients who were diagnosed with or suspected of immunemediated disorders of the CNS or PNS. These patients were seen by us or by clinicians at other institutions in Japan. To screen for synaptic cell surface autoantigens, we selected serum samples from 116 patients diagnosed with or suspected of immune-mediated encephalitis (59 males and 57 females), which included 76 limbic encephalitis, 24 encephalitis, nine encephalopathy, four anti-NMDA receptor encephalitis, and three Hashimoto encephalopathy cases. These patients presented with subacute onset of some CNS symptoms, including cognitive impairment, confusion/disorientation, and/or seizures. For the first screening, these 116 samples with encephalitis (and also 49 samples with other immunemediated neurological disorders described in the following sentence) were tested for binding to the cell surface of cultured rat hippocampal neurons. For the second round of screening for binding to the cell surface of COS7 cells expressing the $\mathrm{GABA}_{\mathrm{A}}$ receptor, we tested serum samples from all of the 116 patients with encephalitis and an additional 94 control subjects ( 54 males and 40 females): 49 patients ( 32 males and 17 females) with or suspected of other immune-mediated neurological disorders, including 35 neuromyotonia, six cramp-fasciculation syndrome, three myasthenia gravis, two Morvan syndrome, one stiff-person syndrome, one Guillain-Barre syndrome, and one chronic inflammatory demyelinating polyneuropathy case; 22 patients ( 10 males and 12 females) with neurodegenerative diseases, including seven amyotrophic lateral sclerosis, six spinocerebellar degeneration, five multiple system atrophy, two Parkinson's disease, one corticobasal degeneration, and one frontotemporal lobar degeneration case; and 23 healthy individuals (12 males and 11 females). The study population and control subjects contained 19 patients with the complications of thymoma (including 12 invasive thymoma cases). The serum samples of Patient 1 and Patient 2 used for the present screening were both from their initial episodes of encephalitis (Table 1). Due to the current unavailability of patients' CSF samples, only the serum samples were used in the present study.

Antibodies. The antibodies used in this study included the following: rabbit polyclonal antibodies to $\mathrm{GABA}_{\mathrm{A}}$ receptor $\alpha 2$ (catalog \#600-401D45 RRID:AB_11182018; Rockland Immunochemicals), $\alpha 5$ (catalog \#AB9678 RRID:AB_570435; Millipore), $\beta 3$ (catalog \#ab4046 RRID: AB_2109564; Abcam), $\gamma 2$ (extracellular epitope, catalog \#224 003 RRID: AB_2263066; Synaptic Systems), and AMPA receptor GluA1 (catalog \#AB1504 RRID:AB_2113602; Millipore; and extracellular epitope, cata$\log$ \#PC246-100UG RRID:AB_564636; Millipore); guinea pig polyclonal antibodies to vGAT (catalog \#131005 RRID:AB_1106810; Synaptic Systems) and vGluT1 (catalog \#AB5905 RRID:AB_2301751; Millipore); and mouse monoclonal antibodies to $\mathrm{GABA}_{\mathrm{A}}$ receptor $\alpha 1$ (catalog \#75-136 RRID:AB_2108811; NeuroMab), $\beta 1$ (catalog \#75-137 RRID:AB_2109406; NeuroMab), $\beta 2 / \beta 3$ (extracellular epitope, catalog \#MAB341 RRID: AB_2109419; Millipore), $\beta$-catenin (catalog \#610153 RRID:AB_397554; BD Biosciences), gephyrin (catalog \#147 021 RRID:AB_1279448; Synaptic Systems), PSD-95 (catalog \#MA1-046 RRID:AB_2092361; Thermo Scientific), and N-cadherin (catalog \#610921 RRID:AB_398236; BD Biosciences).

Plasmid construction. The cDNAs of rat GABA receptor $\alpha 1$ (NM_183326), $\alpha 2$ (NM_001135779), $\alpha 5$ (NM_017295), $\beta 1$ (NM_012956), and $\beta 3$ (NM_017065) were cloned from rat brain total RNA by RT-PCR. These cDNAs were subcloned into pCAGGS vector. Dr. Bernhard Lüscher (Pennsylvania State University) kindly provided pRK5:Myc-mouse $\mathrm{GABA}_{\mathrm{A}}$ receptor $\gamma 2$ (Fang et al., 2006).

Rat $\mathrm{GABA}_{\mathrm{A}}$ receptor $\beta 3$ subunit was knocked down by the miR-RNAi system (Life Technologies). BLOCK-iT RNAi Designer was used to select the targeting sequences and the following targeting sequences were used: miR- $\beta 3$-211, $5^{\prime}$-AGCATCGACATGGTTTCTGAA-3' (an alternative sequence: miR- $\beta 3$-347, $5^{\prime}$-TCTGGGTGCCTGACACATATT-3'; both sequences yielded the same results) and miR-LacZ ( $\beta$-galactosidase), $5^{\prime}$-GACTACACAAATCAGCGATTT- ${ }^{\prime}$ ' as a negative control. After subcloning these oligonucleotides into pcDNA6.2-EmGFP-miR, the premiRNA expression cassette of pcDNA6.2-EmGFP-miR was transferred to pCAGGS vector with a $\beta$-actin promoter. The resultant miR constructs were validated for the knock down of cotransfected rat $\mathrm{GABA}_{\mathrm{A}}$ receptor $\beta 3$ expression in HEK293T cells by Western blotting (see Fig. $3 A)$. Rat $\mathrm{GABA}_{\mathrm{A}}$ receptor $\beta 3$ subunit rescue construct [miR- $\beta 3-211-$ resistant $\beta 3$ (res $\beta 3$ ) in pCAGGS], which has two different nucleotides in the target sequences, was generated using site-directed mutagenesis (5' -AACATCGACATCGCCAGCATTGATATGGTTTCTGAAGTCAACAT-3'; changed nucleotides are shown in italic font). All PCR products were analyzed by DNA sequencing (Functional Genomics Facility, National Institute for Basic Biology).

Immunofluorescence analysis of cultured hippocampal neurons. Cultured rat hippocampal neurons $\left(5 \times 10^{4}\right.$ cells $)$ were obtained from embryonic day 18-19 embryos and seeded onto poly-L-lysine-coated 12 $\mathrm{mm}$ coverslips in 24 well dishes. For selecting the serum samples that bind to neuronal cell surface, live neurons (21-28 DIV) were incubated with the serum from 116 patients diagnosed with or suspected of immune-mediated encephalitis for $1 \mathrm{~h}$ at $37^{\circ} \mathrm{C}$ (diluted 1:100). The neurons were subsequently fixed with $4 \%$ paraformaldehyde/120 mM su-

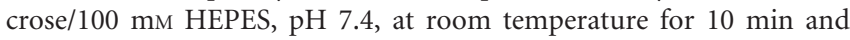
blocked with PBS containing $10 \mathrm{mg} / \mathrm{ml}$ BSA for $15 \mathrm{~min}$. The bound human Ig (IgG) was visualized using Cy3-conjugated secondary antibody. For Figure $1 D$, live neurons were incubated with the patient serum (diluted 1:200) together with anti-GABA receptor $\gamma 2$ antibody (against the extracellular epitope) for $30 \mathrm{~min}$ at $37^{\circ} \mathrm{C}$. The neurons were fixed and labeled by Cy3-conjugated human IgG and Alexa Fluor 488-conjugated rabbit IgG antibodies. The neurons were then permeabilized and incubated with anti-gephyrin antibody, followed by staining with Alexa Fluor 647-conjugated mouse IgG antibody.

For Figure 3, knock down of the $\mathrm{GABA}_{\mathrm{A}}$ receptor $\beta 3$ subunit was performed using the miR-RNAi system as described previously (Fukata et al., 2013). Briefly, hippocampal neurons (10 DIV) were transfected with the knock-down vector (miR-LacZ or miR- $\beta 3$ ) with or without rescue $\beta 3$ construct by Lipofectamine 2000. At $5 \mathrm{~d}$ after transfection, live 
neurons were incubated with anti-GABA $\mathrm{A}_{\mathrm{A}}$ receptor $\beta 2 / \beta 3$ subunit antibody (against the extracellular epitope) or the patient serum (diluted 1:200) together with anti- $\gamma 2$ subunit antibody (against the extracellular epitope) for $30 \mathrm{~min}$ at $37^{\circ} \mathrm{C}$. The neurons were fixed and blocked with PBS containing $10 \mathrm{mg} / \mathrm{ml}$ BSA for $30 \mathrm{~min}$ on ice. The $\beta 3$ subunit or the bound human IgG and $\gamma 2$ were visualized using Cy3-conjugated and Alexa Fluor 647-conjugated secondary antibodies, respectively. Neurons transfected with the knock-down vector were reported by co-cistronic expression of EmGFP. To quantify the effect of the knock down (Fig. $3 D$ ), we randomly chose neurons from two separate cultures and made the intensity profile along the lines (total $\sim 100 \mu \mathrm{m}$ in length) in somatodendritic regions (LAS AF software; Leica Microsystems). The number of clusters labeled by $\beta 2 / \beta 3$ antibody or human IgG (threshold was set at 1000 arbitrary units of mean fluorescent intensity) was counted. Because the expression of rescue $\beta 3$ construct enhanced fluorescence intensity of the clusters, the images of miR- $\beta 3-211+$ res $\beta 3$-transfected neurons were acquired with $50 \%$ of laser power used for miR-LacZ + GST- or miR- $\beta 3-211$ + GST-transfected neurons (GST was used as a mock vector).

For Figures $1 D$ and 3, fluorescent images were captured with a confocal laser scanning microscopy system (TCS SP5 II; Leica) equipped with an HCX Plan Apochromat $63 \times / 1.40$ numerical aperture (NA) oilimmersion objective lens combining with the Leica HyD detectors. For Figures 2, 4, and 5, images were captured with a system (LSM5 Exciter; Carl Zeiss) equipped with a Plan Apochromat $63 \times / 1.40$ NA oilimmersion objective lens.

Immunoprecipitation and mass spectrometry. Rat hippocampal neurons $\left(5 \times 10^{5}\right.$ cells/well $)$ were seeded in six well plates. The neurons were incubated with the patient serum (diluted 1:50) for $1 \mathrm{~h}$ at $37^{\circ} \mathrm{C}$. The neurons were washed and subsequently lysed with buffer A containing the following: $20 \mathrm{~mm}$ Tris-HCl, pH 8.0, 1 mм EDTA, $100 \mathrm{~mm} \mathrm{NaCl}, 1.3 \%$ Triton X-100, and $50 \mu \mathrm{g} / \mathrm{ml}$ PMSF. The lysates were cleared by centrifugation at $10,000 \times g$ for $5 \mathrm{~min}$ at $4^{\circ} \mathrm{C}$. The immune complexes were precipitated with Protein A Sepharose (GE Healthcare). The immunoprecipitates were separated by SDS-PAGE and the gels were subsequently analyzed by silver staining and Western blotting. All of the specific protein bands were excised from a silver-stained gel and analyzed with liquid chromatography-tandem mass spectrometry (LC-MS/MS) as described previously (Fukata et al., 2010). The gel pieces with the corresponding molecular weights in the control serum sample were also analyzed to rule out nonspecific binding to human serum antibodies.

Cell-based binding assay. COS7 cells were transfected with the indicated $\mathrm{GABA}_{\mathrm{A}}$ receptor subunits. Twenty-four hours after transfection, the cells were fixed with $4 \%$ paraformaldehyde/120 mM sucrose $/ 100 \mathrm{~mm}$ HEPES, pH 7.4, at room temperature for $10 \mathrm{~min}$ and blocked with PBS containing $10 \mathrm{mg} / \mathrm{ml} \mathrm{BSA}$ for $15 \mathrm{~min}$. The fixed cells were incubated with the patient serum (diluted 1:10), followed by staining with the Cy3conjugated secondary antibody. The cells were then permeabilized with $0.1 \%$ Triton X-100 for $10 \mathrm{~min}$, blocked with PBS containing $10 \mathrm{mg} / \mathrm{ml}$ $\mathrm{BSA}$, and incubated with antibodies to individual $\mathrm{GABA}_{\mathrm{A}}$ receptor subunits, followed by staining with the Alexa Fluor 488-conjugated secondary antibody. For the second round of screening, serum samples from all of the 116 patients with encephalitis and 94 control subjects were tested for binding to COS7 cells expressing the $\mathrm{GABA}_{\mathrm{A}}$ receptor $\alpha 1 / \beta 3 / \gamma 2$ subunits. We confirmed that any serum samples did not bind to untransfected cells that did not express the $\mathrm{GABA}_{\mathrm{A}}$ receptor subunits through distinguishing untransfected cells with Hoechst dye (33342; Invitrogen) nucleic acid staining (Figs. $2 A, 4 A$ ) and that neither the patient sera nor the control sera bound to COS7 cells that had not been treated with Lipofectamine transfection reagent (data not shown). To quantify the intensity of bound human IgG (Fig. 2B), we randomly chose 10 cells and measured the mean intensities in green and red channels. The ratio of the human IgG intensity to the $\mathrm{GABA}_{\mathrm{A}}$ receptor subunit intensity was graphed.

The identities of human and rat $\mathrm{GABA}_{\mathrm{A}}$ receptor $\alpha 1, \beta 3$, and $\gamma 2$ subunits in their amino acid sequence are $100 \%, 97 \%$, and $99 \%$, respectively; and that of the human and mouse $\gamma 2$ subunit is $99 \%$, suggesting that the results obtained by using rat or mouse $\mathrm{GABA}_{\mathrm{A}}$ receptor constructs and rat neurons do not affect the interpretation of our results. Cell-based binding assay for LGI1, CASPR2, and DCC (Fig. 4A) was described previously (Ohkawa et al., 2013).
Cell-based ELISA. Cell-based ELISA testing for LGI1, CASPR2, and DCC was described previously (Ohkawa et al., 2013) and the ELISA testing for the $\mathrm{GABA}_{\mathrm{A}}$ receptor $\beta 3$ subunit basically followed this procedure. Briefly, plasmids $(0.1 \mu \mathrm{g} /$ well for LGI1, CASPR2, and $\beta 3 ; 0.06$ $\mu \mathrm{g} /$ well for DCC) were lipofected into HEK293T cells grown in polyethylenimine-coated 96 -well plates $\left(3 \times 10^{4}\right.$ cells/well; Nunclon TC; Nunc). After a $24 \mathrm{~h}$ incubation, the cells were treated with the serially diluted sera (1:50,150,450, and 1350) from patients and control subjects together in the same plate for $15 \mathrm{~min}$ at $37^{\circ} \mathrm{C}$. The cells were washed and fixed with $4 \%$ paraformaldehyde for $15 \mathrm{~min}$. After washing and blocking, the cells were incubated with an HRP-conjugated anti-human IgG antibody in a 1:2000 dilution for $15 \mathrm{~min}$ at $37^{\circ} \mathrm{C}$. After washing, the cellbound human IgG was detected using Ultra-TMB substrate solution (Thermo Scientific). The colorimetric reaction was stopped upon the addition of $2 \mathrm{~m}$ sulfuric acid and the resulting plates were measured at 450 $\mathrm{nm}$ absorption with MULTISKAN FC microplate reader (Thermo Scientific). Wells containing nontransfected cells were used to subtract the background signals. The absorbance at a dilution of 1:50 was used as the antibody value for an individual patient. We previously determined the best cutoff point to predict the patient with limbic encephalitis from LGI1-ELISA values using a receiver operating characteristic curve composed of sensitivity and false-positive rate (Ohkawa et al., 2013). We showed that the ELISA test for LGI1 is useful for the diagnosis of limbic encephalitis with high specificity ( $94.2 \%)$, sensitivity (49.2\%), and positive predictive value $(85.3 \%)$ at the 0.8 cutoff point and that the ELISA for CASPR2 is useful for the diagnosis of neuromyotonia with high specificity $(96.5 \%)$, sensitivity $(26.7 \%)$, and positive predictive value $(66.7 \%)$ at the 0.3 cutoff point (Ohkawa et al., 2013).

Tests of effects of $G A B A_{A}$ receptor autoantibodies. To determine the effect of the patients' serum antibodies on the surface or synaptic $\mathrm{GABA}_{\mathrm{A}}$ receptor density, cultured rat hippocampal neurons $(\sim 30 \mathrm{DIV})$ were treated with the indicated serum samples for $2 \mathrm{~d}$. $4.5 \mu \mathrm{l}$ of the serum was added daily to $300 \mu \mathrm{l}$ of each culture medium (final $3 \%$ concentration). After washing, live neurons were then incubated with an antibody to an extracellular epitope of $\mathrm{GABA}_{\mathrm{A}}$ receptor $\gamma 2$ for $15 \mathrm{~min}$ at $37^{\circ} \mathrm{C}$. After fixation, the surface-expressed $\gamma 2$ subunit was visualized with the Cy3conjugated antibody. After permeabilizing neurons, the neurons were incubated with anti-gephyrin and vGAT antibodies, followed by staining with Alexa Fluor 488- and Alexa Fluor 647-conjugated secondary antibodies, respectively. Serum-treated sister cultures were also independently stained with anti-GABA $A_{A}$ receptor $\beta 3$ subunit antibody (the intracellular epitope) after cell permeabilization to visualize the $\mathrm{GABA}_{\mathrm{A}}$ receptors containing the $\beta 3$ subunit. To quantify the synaptic $\mathrm{GABA}_{\mathrm{A}}$ receptors, we randomly chose dendrites and analyzed the number of $\mathrm{GABA}_{\mathrm{A}}$ receptor $\gamma 2$ and $\beta 3$ clusters along dendrites (20 $\mu \mathrm{m}$ length). Three to 10 neurons were examined from each separate culture. Synaptic $\gamma 2$ and $\beta 3$ clusters that were adjacent to both vGAT and gephyrin and bigger than $1 / \pi \mu \mathrm{m}$ in diameter (threshold was set at 70 arbitrary units of mean fluorescent intensity) were counted. The quantification of gephyrin clusters apposed to vGAT was analyzed by the same criteria. The quantification of synaptic AMPA receptor was described previously (Ohkawa et al., 2013).

Biotinylation of cell surface proteins was performed as described previously (Hughes et al., 2010). Briefly, neurons were incubated with 2.3 $\mathrm{mm}$ Sulfo-NHS-Biotin (Thermo Scientific) for $30 \mathrm{~min}$ at $4^{\circ} \mathrm{C}$. Neurons were then incubated with quenching buffer containing $100 \mathrm{~mm}$ glycine for $30 \mathrm{~min}$ and lysed in buffer B containing the following: $20 \mathrm{~mm}$ Tris$\mathrm{HCl}, \mathrm{pH}$ 8.0, 1 mм EDTA, $100 \mathrm{~mm} \mathrm{NaCl}, 1 \%$ SDS, and $50 \mu \mathrm{g} / \mathrm{ml}$ PMSF. After a 20 min extraction, the lysates were diluted with 10 volumes of buffer B containing $1 \%$ Triton X-100 instead of SDS. After centrifugation at $20,000 \times g$ for $20 \mathrm{~min}$, the supernatant was incubated with NeutrAvidin agarose beads (Thermo Scientific) for $12 \mathrm{~h}$ at $4^{\circ} \mathrm{C}$. The isolated surface proteins were separated by SDS-PAGE and analyzed by Western blotting with indicated antibodies. For the quantification, ImageJ software was used.

Electrophysiology. Cultured rat hippocampal neurons $\left(1.5 \times 10^{4}\right.$ cells $)$ were seeded onto poly-L-lysine-coated $12 \mathrm{~mm}$ coverslips in 24 well dishes. Neurons (33-46 DIV) were treated with control serum or patients' serum samples containing $\mathrm{GABA}_{\mathrm{A}}$ receptor antibodies for $24 \mathrm{~h}$. 
A

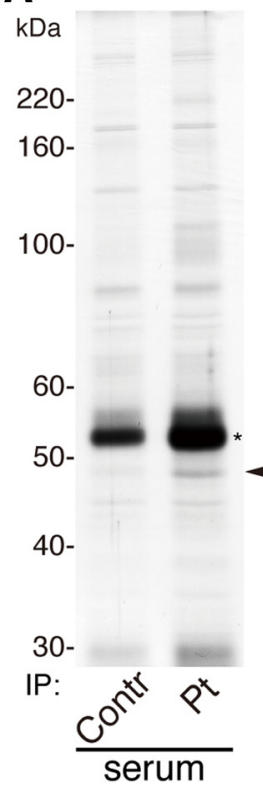

C

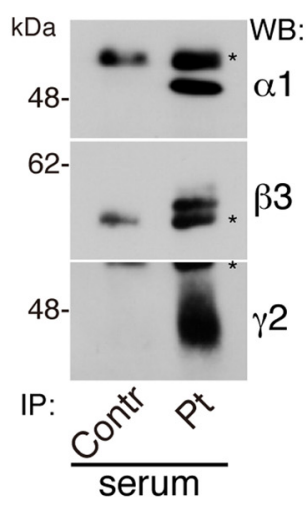

B

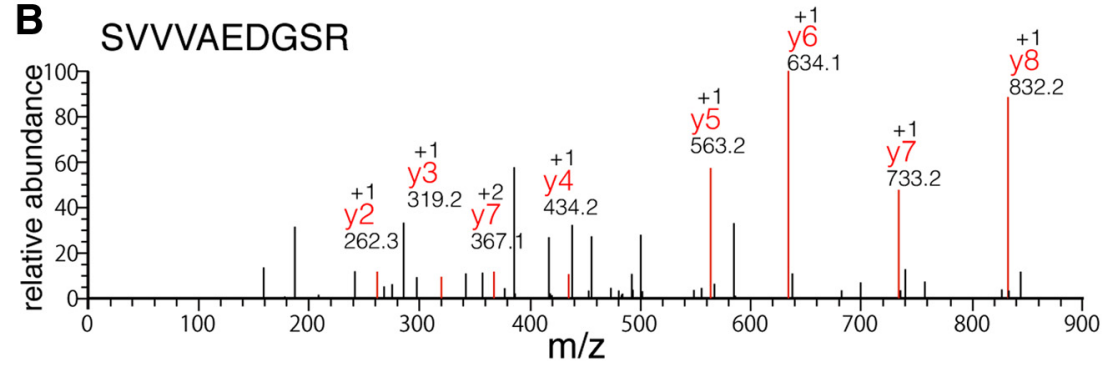

$\mathrm{GABA}_{\mathrm{A}} \mathrm{R} \alpha 1$

MKKSRGLSDYLWAWTLILSTLSGRSYGQPSODELKDNTTVFTRILDRLLD GYDNRLRPGLGERVTEVKTDIFVTSFGPVSDHDMEYTIDVFFROSWKDER LKFKGPMTVLRLNNLMASKIWTPDTFFHNGKKSVAHNMTMPNKLLRITED GTLLYTMRLTVRAECPMHLEDFPMDAHACPLKFGSYAYTRAEVVYEWTRE PARSVVVAEDGSRLNOYDLLGQTVDSGIVQSSTGEYVVMTTHFHLKRKIG YFVIQTYLPCIMTVILSQVSFWLNRESVPARTVFGVTTVLTMTTLS ISAR NSLPKVAYATAMDWF IAVCYAFVFSALIEFATVNYFTKRGYAWDGKSVVP EKPKKVKDPLIKKNNTYAPTATSYTPNLARGDPGLATIAKSATIEPKEVK PETKPPEPKKTFNSVSKIDRLSRIAFPLLFGIFNLVYWATYLNREPQLKA РTPHQ

D IF: GABAAR $\gamma 2$ _human IgG_gephyrin
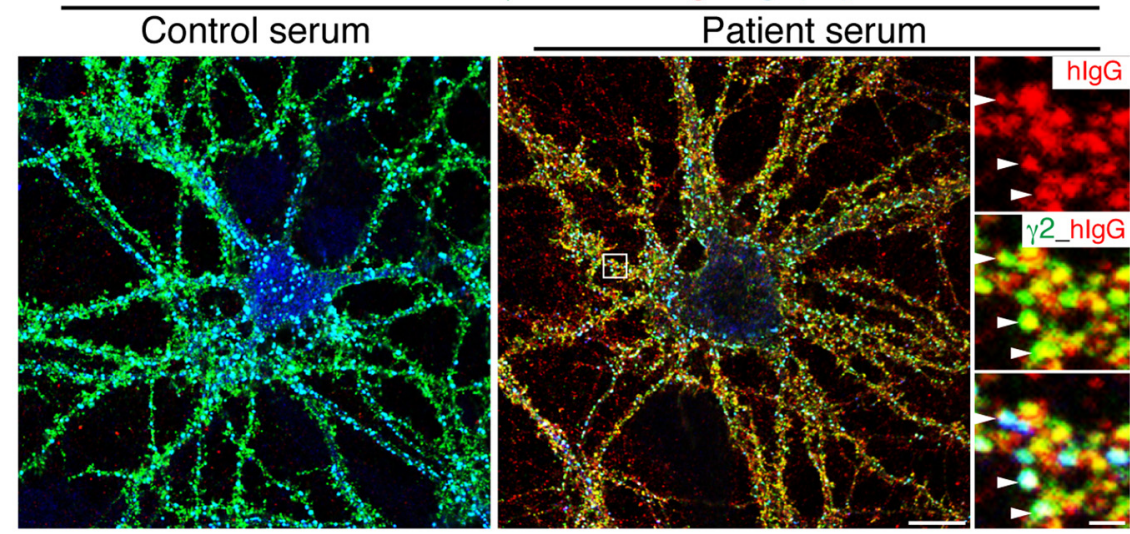

Figure 1. Identification of $G A B A_{A}$ receptor autoantibodies in a patient with autoimmune encephalitis. $A$, Immunoprecipitation of cell surface target proteins with patient's serum antibodies. The immunoprecipitates of serum antibodies bound to rat hippocampal neurons were analyzed by SDS-PAGE with silver staining. The specific band at $48 \mathrm{kDa}$ (arrowhead) was analyzed by the LC-MS/MS. $\boldsymbol{B}, \mathrm{MS} / \mathrm{MS}$ spectra of a peptide unique for the $\mathrm{GABA}_{A}$ receptor $\alpha 1$ subunit ( $\mathrm{m} / \mathrm{z}$ value of the parent ion, 509.74 ) obtained from the trypsinized protein band shown in $\boldsymbol{A}$ (arrowhead). The matched fragment $y^{+}$ion series is indicated in red. Identified peptides in the amino acid sequence of $\mathrm{GABA}_{A}$ receptor $\alpha 1$ are indicated in red. The accession number is P62813. The patient serum used came from the initial episode of encephalitis of Patient 1. C, Western blotting with the subunit specific antibodies showed that the $\alpha 1, \beta 3$, and $\gamma 2$ subunits of the $G A B A_{A}$ receptor were present in the immunoprecipitate by the patient serum antibodies. Asterisks indicate the position of the human lgG heavy chain $\left(A, C\right.$. $D$, Patient serum antibodies bind to the inhibitory $G A B A_{A}$ receptors at the cell surface of rat hippocampal neurons. The serum reactivity (red; human $\mathrm{lg} G$ ) was well overlapped with surface-expressed $\gamma 2$ subunits of $G_{A B A_{A}}$ receptor (green), which were apposed to gephyrin scaffold (blue; marked by arrowheads). Magnified view of the region indicated by a white square. Scale bars, $10 \mu \mathrm{m}$ (1 $\mu \mathrm{m}$, magnified). IP, immunoprecipitation; Contr, control; Pt, patient; GABA $_{A} R$, $G_{A B A_{A}}$ receptor; WB, Western blotting; IF, immunofluorescence; hlgG, human Ig.

Nine microliters of the serum was added to $300 \mu$ l of the culture medium (final $3 \%$ concentration). The culture slips were transferred to a recording chamber mounted on the microscope stage (BX51WI; Olympus) and continuously superfused with an artificial CSF (ACSF) containing the following (in $\mathrm{mM}$ ): $138.6 \mathrm{NaCl}, 3.35 \mathrm{KCl}, 2.5 \mathrm{CaCl}_{2}, 1.0 \mathrm{MgCl}_{2}, 21.0$ $\mathrm{NaHCO}_{3}, 0.6 \mathrm{NaH}_{2} \mathrm{PO}_{4}$, and 10.0 glucose equilibrated with $95 \% \mathrm{O}_{2}$ and $5 \% \mathrm{CO}_{2}, \mathrm{pH} 7.4$, at room temperature. Flow rate was $1.0 \mathrm{ml} / \mathrm{min}$ and all experiments were performed at room temperature. Synaptic currents were recorded from the hippocampal neurons by whole-cell voltage clamping (Satake and Imoto, 2014) under Nomarski optics with a waterimmersion objective $(63 \times / 0.90 \mathrm{NA}$; Olympus). Patch-clamp electrodes (resistance, 3-6 M 2 ) were filled with an internal solution containing the following (in $\mathrm{mm}$ ): 150.0 Cs-methanesulfonate, $5.0 \mathrm{KCl}, 0.1$ EGTA, 5.0 HEPES, 3.0 Mg-ATP, and 0.4 $\mathrm{Na}_{3}-\mathrm{GTP}$, pH 7.4. Membrane potential was held with a voltage-clamp amplifier (EPC-10; HEKA Elektronik) controlled by PatchMaster software (HEKA Elektronik). Currents were filtered at $3 \mathrm{kHz}$ and digitized at $20 \mathrm{kHz}$. To record miniature IPSCs (mIPSCs), neurons were held at $-20 \mathrm{mV}$ in the presence of $1 \mu \mathrm{M}$ tetrodotoxin (TTX), $20 \mu \mathrm{M}$ CNQX, and $50 \mu \mathrm{M}$ APV (Satake et al., 2004). To record AMPA-receptor-mediated miniature EPSCs (mEPSCs), neurons were held at $-80 \mathrm{mV}$ in the presence of $1 \mu \mathrm{M}$ TTX, $10 \mu \mathrm{M}$ bicuculline, and $50 \mu \mathrm{M}$ APV. The Mini Analysis program (Synaptosoft Systems) was used to detect and measure mIPSCs and mEPSCs; the threshold for detection of events was threefold more than variance $\left(\sigma^{2}\right)$ of basal noise. All data were obtained on age-matched sister cultures by an experimenter who was blinded with regard to serum treatment.

Statistical analysis. Statistical comparisons between two groups were performed by the Student's $t$ test. Statistical comparisons between multiple groups were performed by one-way ANOVA with Tukey's post hoc analysis. When the sample sizes were unequal, Scheffe's post hoc analysis was used. For Figure $6 C$, statistical analysis of cumulative distribution of the mIPSC amplitude was performed using two-way ANOVA. Error bars indicate SEM in all figures. 
Table 1. Clinical features of patients with encephalitis and $G_{A B A_{A}}$ receptor antibodies

\begin{tabular}{|c|c|c|c|c|c|c|c|c|c|c|c|}
\hline \multirow[b]{3}{*}{ Pt\# } & \multirow[b]{3}{*}{ Age } & \multirow[b]{3}{*}{ Sex } & \multirow{2}{*}{\multicolumn{2}{|c|}{ At onset of encephalitis ${ }^{a}$}} & \multicolumn{2}{|l|}{ History } & \multicolumn{2}{|c|}{ Autoantibodies at onset of encephalitis } & \multirow[b]{3}{*}{ Treatment } & \multirow[b]{3}{*}{ Outcome } & \multirow[b]{3}{*}{ Reference } \\
\hline & & & & & \multirow{2}{*}{$\begin{array}{l}\text { Cancer and other } \\
\text { remarks (age) }\end{array}$} & \multirow{2}{*}{$\begin{array}{l}\text { Autoimmune diseases } \\
\text { (age); autoantibodies }{ }^{b}\end{array}$} & \multirow[b]{2}{*}{ In original case report ${ }^{b}$} & \multirow{2}{*}{$\begin{array}{l}\text { Determined in the } \\
\text { present study }\end{array}$} & & & \\
\hline & & & Symptoms/signs & Brain MRI (T2) & & & & & & & \\
\hline 1 & 46 & M & $\begin{array}{l}\text { Subacute onset of } \\
\text { aphasia, visual } \\
\text { hallucination, } \\
\text { and generalized } \\
\text { seizures with } \\
\text { delirium; residual } \\
\text { thymoma }\end{array}$ & $\begin{array}{l}\text { Multifocal signal } \\
\text { abnormalities }\end{array}$ & $\begin{array}{l}\text { Invasive thymoma (42); } \\
\text { thymectomy, radiation, } \\
\text { and chemotherapy (42) }\end{array}$ & $\begin{array}{l}\text { MG (42); Anti-AchR, } \\
500 \mathrm{nm;} \\
\text { anti-VGKC, } 63.7 \mathrm{pm} \\
\text { (serum) }\end{array}$ & $\begin{array}{l}\text { Anti-AchR, } 130 \mathrm{nm;} \\
\text { anti-VGKC, } 649 \text { pm } \\
\text { (serum) }\end{array}$ & $\begin{array}{l}\text { Anti-GABA }{ }_{A} R \text {, } \\
\text { anti-LGI1, and } \\
\text { anti-DCC } \\
\text { (serum) }\end{array}$ & $\begin{array}{l}\text { Corticosteroids and } \\
\text { IVIg; AED }\end{array}$ & $\begin{array}{l}\text { Epileptic seizures } \\
\text { disappeared; } \\
\text { severe cognitive } \\
\text { impairment and } \\
\text { psychological } \\
\text { symptoms } \\
\text { remained }\end{array}$ & $\begin{array}{l}\text { Miyazaki } \\
\text { et al., } \\
2012\end{array}$ \\
\hline 2 & 59 & $\mathrm{~F}$ & $\begin{array}{l}\text { Subacute onset of } \\
\text { amnesia (short-term } \\
\text { memory impairment), } \\
\text { disorientation, and } \\
\text { no evidence of } \\
\text { recurrent thymoma; } \\
10 \text { months later, } \\
\text { progressive memory } \\
\text { impairment and } \\
\text { recurrence of } \\
\text { thymoma }\end{array}$ & $\begin{array}{l}\text { Multifocal signal } \\
\text { abnormalities in } \\
\text { the medial } \\
\text { temporal lobe, } \\
\text { insular cortex, } \\
\text { frontobasal cortex, } \\
\text { and cingulated } \\
\text { gyrus }\end{array}$ & $\begin{array}{l}\text { Invasive thymoma (56); } \\
\text { thymectomy and } \\
\text { radiation (56); } \\
\text { carbamazepine ( } 200 \\
\text { mg/d) } \\
\text { for postherpetic } \\
\text { neuralgia (57-63) }\end{array}$ & NA & $\begin{array}{l}\text { Anti-AchR, anti-Hu, and } \\
\text { anti-Yo, negative; } \\
\text { anti-VGKC, } 403 \text { pM } \\
\text { (serum) }\end{array}$ & $\begin{array}{l}\text { Anti-GABA }{ }_{A} \mathrm{R}, \\
\text { anti-CASPR2, } \\
\text { and anti-DCC } \\
\text { (serum) }\end{array}$ & $\begin{array}{l}\text { Chemotherapy for } \\
\text { recurrent } \\
\text { thymoma } \\
\text { (carboplatin } \\
\text { and etoposide) }\end{array}$ & $\begin{array}{l}\text { Mental state } \\
\text { partially } \\
\text { improved }\end{array}$ & $\begin{array}{l}\text { Ohshita } \\
\text { et al., } \\
2006\end{array}$ \\
\hline
\end{tabular}

${ }^{a}$ The serum samples at the onset of encephalitis were used for the present screening.

${ }^{b}$ Anti-VGKC, normal $<100$ pm; anti-AchR, normal $<0.2$ nм.

MG, Myasthenia gravis; AchR, acetylcholine receptor; IVIg, intravenous immunoglobulin; AED, antiepileptic drug; NA, not applicable.

\section{Results}

Identification of $\mathrm{GABA}_{\mathrm{A}}$ receptor autoantibodies in patients with encephalitis

To identify novel cell surface autoantigens involved in autoimmune encephalitis, we analyzed serum samples from 116 patients with or suspected of immune-mediated encephalitis (see Study Population section in Materials and Methods). We first screened serum antibodies for binding to the cell surface of cultured rat hippocampal neurons. The serum antibodies from 37 patients bound to the neuronal cell surface (data not shown). Target proteins were immunoprecipitated from cultured neurons with the bound serum antibodies and identified by mass spectrometry. We found the previously reported autoantibodies to LGI1, AMPA receptor, CASPR2, DPP10, and DCC in patients with encephalitis (data not shown) (Lai et al., 2009; Irani et al., 2010; Lai et al., 2010; Ohkawa et al., 2013). In addition, a protein with a molecular mass of $48 \mathrm{kDa}(\mathrm{p} 48)$ was specifically detected in the immunoprecipitate by serum antibodies from one patient (Fig. 1A), who was originally diagnosed as having invasive thymoma with the complications of myasthenia gravis and then developed encephalitis associated with VGKC-complex antibodies (Patient 1, Table 1) (Miyazaki et al., 2012). The molecular identity of $\mathrm{p} 48$ was determined by LC-MS/MS (Fig. 1B). Molecular weights of seven peptide fragments derived from $\mathrm{p} 48$ coincided with those from the rat $\mathrm{GABA}_{\mathrm{A}}$ receptor $\alpha 1$ subunit: LLDGYDNR, ITEDGTLLYTMR, AEVVYEWTR, SVVVAEDGSR, NNTYAPTATSYTPNLAR, GDPGLATIAK, and EVKPETKPPEPK. The estimated molecular weight of rat $\mathrm{GABA}_{\mathrm{A}}$ receptor $\alpha 1(51.7 \mathrm{kDa})$ was close to that of $\mathrm{p} 48$. In addition, peptide fragments coinciding with those from the $\mathrm{GABA}_{\mathrm{A}}$ receptor $\beta 3$ subunit (NVVFATGAYPR and IKIPDLTDVNAIDR) were present in the same immunoprecipitate (the corresponding band at $54.2 \mathrm{kDa}$ was masked by the human IgG heavy chain). Western blotting with antibodies specific to the $\alpha 1, \beta 3$, and $\gamma 2$ subunits of $\mathrm{GABA}_{\mathrm{A}}$ receptor confirmed the immunoprecipitation of heteromeric $\mathrm{GABA}_{\mathrm{A}}$ receptors (Fig. $1 C$ ). Consistently, the serum antibodies showed overlapped signals with inhibitory synapses marked by $\mathrm{GABA}_{\mathrm{A}}$ receptor $\gamma 2$ and gephyrin antibodies in rat hippocampal neurons (Fig. 1D).
$\mathrm{GABA}_{\mathrm{A}}$ receptor autoantibodies are directed to extracellular epitope of the $\beta 3$ subunit

To determine whether the patient serum antibodies bind directly to the $\mathrm{GABA}_{\mathrm{A}}$ receptor and, if so, which of $\mathrm{GABA}_{\mathrm{A}}$ receptor subunits the antibodies recognize, the cell-based binding assay was performed. Because the native $\mathrm{GABA}_{\mathrm{A}}$ receptor is a heteropentamer composed of two $\alpha$, two $\beta$, and one $\gamma$ subunits and the patient serum immunoprecipitated $\alpha 1, \beta 3$, and $\gamma 2$ subunits from hippocampal neurons (Fig. 1C), $\alpha 1, \beta 3$, and $\gamma 2$ subunits were coexpressed to display heteropentameric $\mathrm{GABA}_{\mathrm{A}}$ receptors at the cell surface of COS7 cells. Transfected cells were then fixed and incubated with the patient serum without cell permeabilization. We found that the serum antibodies from Patient 1 robustly reacted to the surface-expressed $\mathrm{GABA}_{\mathrm{A}}$ receptors $(\alpha 1 / \beta 3 / \gamma 2$; Fig. $2 A$, left). Among 19 individual $\mathrm{GABA}_{\mathrm{A}}$ receptor subunits, we then examined the binding to individual $\mathrm{GABA}_{\mathrm{A}}$ receptor subunits $(\alpha 1, \alpha 2, \alpha 5, \beta 1, \beta 3$, and $\gamma 2)$, which are known to be included in $\mathrm{GABA}_{\mathrm{A}}$ receptor heteromers expressed in hippocampus (Pirker et al., 2000). The serum antibodies from Patient 1 strongly reacted to the cells expressing the $\beta 3$ subunit alone and weakly reacted to those expressing the $\gamma 2$ subunit alone, but did not to those expressing the $\alpha 1, \alpha 2, \alpha 5$, or $\beta 1$ subunit alone (Fig. $2 A, B)$. Then, as the second round of screening, we tested serum samples from all of the 116 patients with encephalitis for binding to the cell surface of COS7 cells expressing the $\mathrm{GABA}_{\mathrm{A}}$ receptor $(\alpha 1 / \beta 3 / \gamma 2)$. We additionally tested serum samples from 94 control subjects (see Materials and Methods). We found that another patient (Patient 2) diagnosed with encephalitis had antibodies against the $\mathrm{GABA}_{\mathrm{A}}$ receptor $\alpha 1 / \beta 3 / \gamma 2$ and that the antibodies also strongly recognized the $\beta 3$ subunit, but neither the $\alpha 1$ nor the $\gamma 2$ subunit (Fig. $2 A, B$ ). Patient 2 had invasive thymoma and limbic encephalitis associated with VGKC-complex antibodies (Ohshita et al., 2006) (Table 1). Therefore, the common clinical features between two patients with $\mathrm{GABA}_{\mathrm{A}}$ receptor antibodies are cognitive impairment, multifocal abnormal brain MRI signals, and invasive thymoma. Patient 1 had seizures/status epilepticus, but Patient 2 had no seizure episodes (see Discussion). We did not find any control subjects that bound to the $\mathrm{GABA}_{\mathrm{A}}$ re- 
A
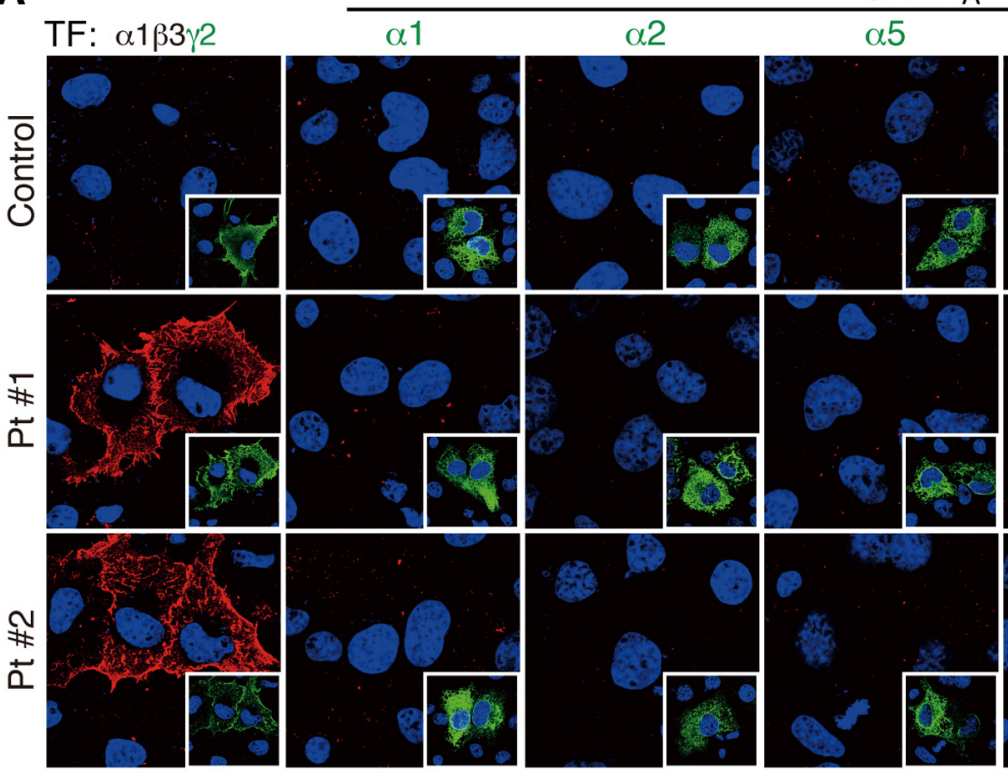

$\mathrm{GABA}_{A} \mathrm{R}$ subunits
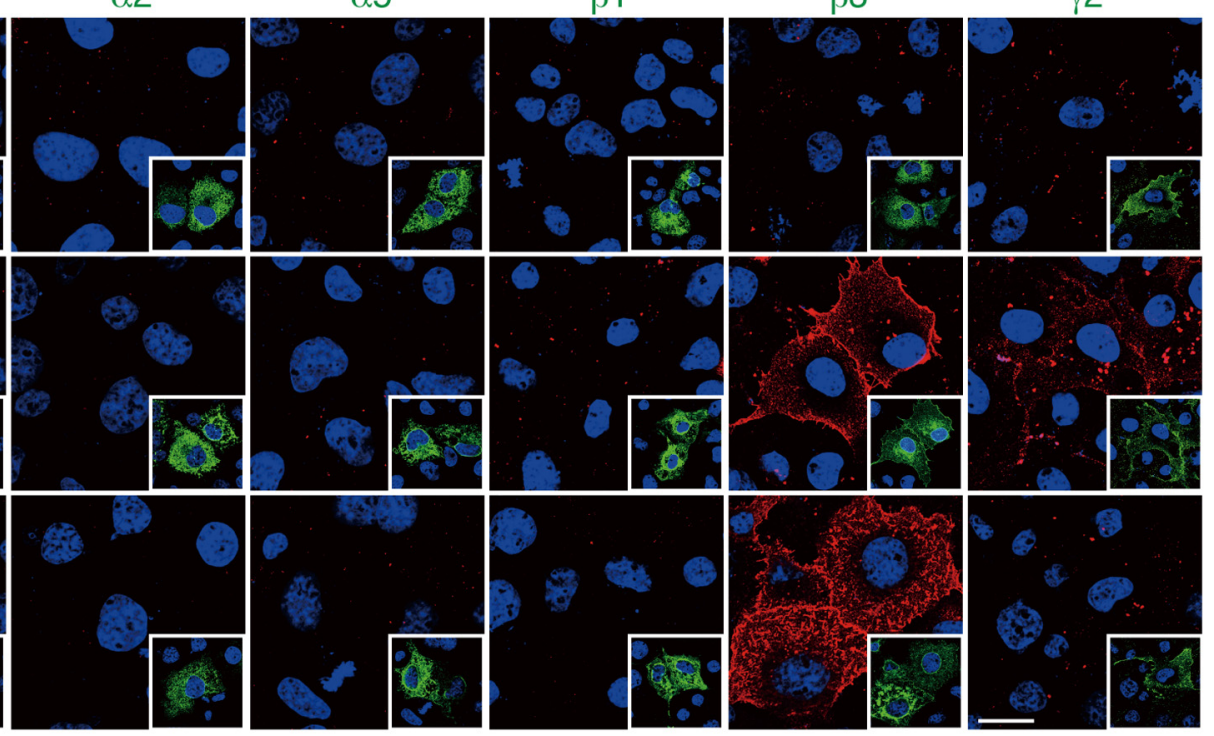

B

\section{C}
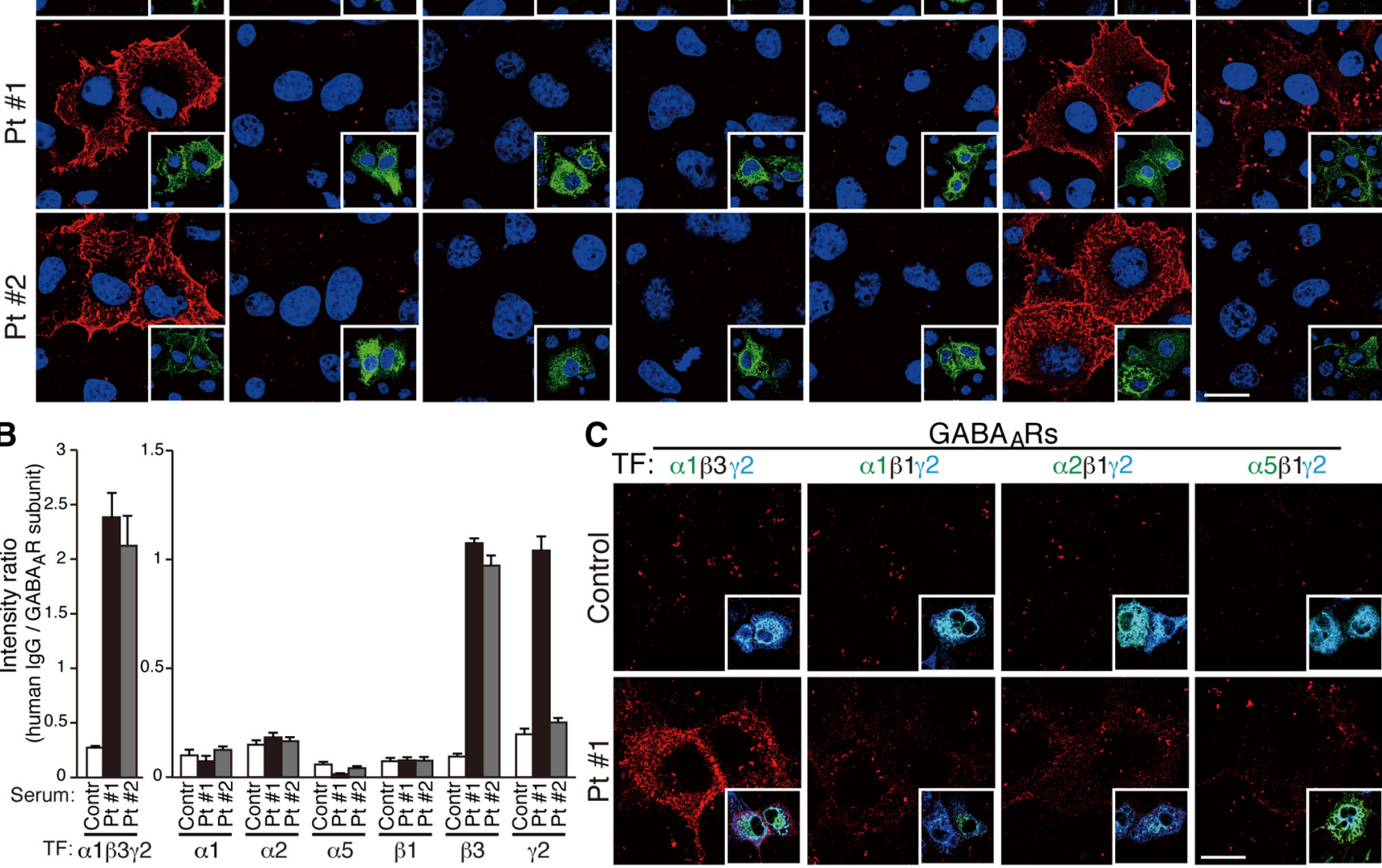

Figure 2. Patients' $G A B A_{A}$ receptor antibodies are directed to extracellular epitope of $\beta 3$ subunit. $A, B, \operatorname{COS} 7$ cells were transfected (TF) to surface express the indicated $G A B A_{A}$ receptor subunits. Transfected cells were fixed and doubly stained with the patient sera (Patient 1 or Patient 2; red, human lg $G$ ) together with the antibodies specific to the individual expressed subunits (green, insets). Nuclear DNA was stained by Hoechst 33342 (blue) to distinguish untransfected cells. To clearly show the weak binding of the serum from Patient 1 to the $\gamma 2$ subunit, the detector gain of the red channel is enhanced upon image acquisition (right, middle). The ratio of the human lgG intensity to the GABA $A_{A}$ receptor subunit intensity was graphed $(\boldsymbol{B})$. Error bars indicate SEM; $n=10$ transfected cells. $C$, COS7 cells were transfected to surface express the indicated heteromeric $G A B A_{A}$ receptors and tested for binding of serum antibodies (red). Transfected cells were detected by staining with the individual $\alpha$ subunit (green) and $\gamma 2$ subunit (blue) antibodies. Merged images are shown in insets. Scale bars, $20 \mu \mathrm{m}$.

ceptor $(\alpha 1 / \beta 3 / \gamma 2$; a representative is shown in Fig. $2 A)$, although this screening might have missed some serum samples that contained antibodies to other $\mathrm{GABA}_{\mathrm{A}}$ receptor subunits than $\alpha 1 / \beta 3 /$ $\gamma 2$. Because neither serum antibody from the two patients bound to COS7 cells expressing the $\alpha$ subunit alone, one may wonder whether the $\alpha$ subunit might not have been efficiently expressed at the cell surface without other subunits. To further examine the possible involvement of $\alpha$ subunit antibodies in the patient serum, COS7 cells were transfected with various combinations of three subunit genes of the $\mathrm{GABA}_{\mathrm{A}}$ receptor, $\alpha 1 / \beta 3 / \gamma 2, \alpha 1 / \beta 1 / \gamma 2$, $\alpha 2 / \beta 1 / \gamma 2$, or $\alpha 5 / \beta 1 / \gamma 2$ (Fig. $2 C$ ). There were no apparent differences in the weak binding of serum antibodies from Patient 1 to three different $\mathrm{GABA}_{\mathrm{A}}$ receptors, $\alpha 1 / \beta 1 / \gamma 2, \alpha 2 / \beta 1 / \gamma 2$, and $\alpha 5 /$ $\beta 1 / \gamma 2$, indicating that the binding of serum antibodies was attributed to the $\gamma 2$ subunit, but not to the $\alpha 1, \alpha 2$, or $\alpha 5$ subunits. Serum from Patient 2 did not show any apparent binding to $\alpha 1 / \beta 1 / \gamma 2, \alpha 2 / \beta 1 / \gamma 2$, or $\alpha 5 / \beta 1 / \gamma 2$ (data not shown). Together, these results indicate that the two patients with immunemediated encephalitis had autoantibodies directed against the
$\mathrm{GABA}_{\mathrm{A}}$ receptor and that the extracellular part of the $\beta 3$ subunit was the antigenic epitope recognized by the patients' $\mathrm{GABA}_{\mathrm{A}}$ receptor antibodies. One of the two patients also had a low level of $\gamma 2$ autoantibodies (Patient 1 ), but neither patient had any autoantibodies to the $\alpha 1, \alpha 2, \alpha 5$, or $\beta 1$ subunit.

$\mathrm{GABA}_{\mathrm{A}}$ receptor containing $\beta 3$ subunit is the main target of the patient serum antibodies

We next investigated whether the $\mathrm{GABA}_{\mathrm{A}}$ receptor is the main target of the patient serum antibodies in neurons. We took advantage of knock-down approach in cultured rat hippocampal neurons. MicroRNAs (miRNA- $\beta 3-211$ and miRNA- $\beta 3-347$ ) for the $\mathrm{GABA}_{\mathrm{A}}$ receptor $\beta 3$ subunit were first validated by the reduced expression of exogenously expressed rat $\mathrm{GABA}_{\mathrm{A}}$ receptor $\beta 3$ in HEK293T cells (Fig. 3A). Then, by cell surface staining with anti- $\beta 2 / \beta 3$ antibody, we quantified the knock-down effect on the $\beta 3$ subunit expression in neurons. When miRNA- $\beta 3-211$ for the $\mathrm{GABA}_{\mathrm{A}}$ receptor $\beta 3$ subunit was expressed in neurons, the number of $\beta 3$ subunit clusters in soma and dendrites that were stained 

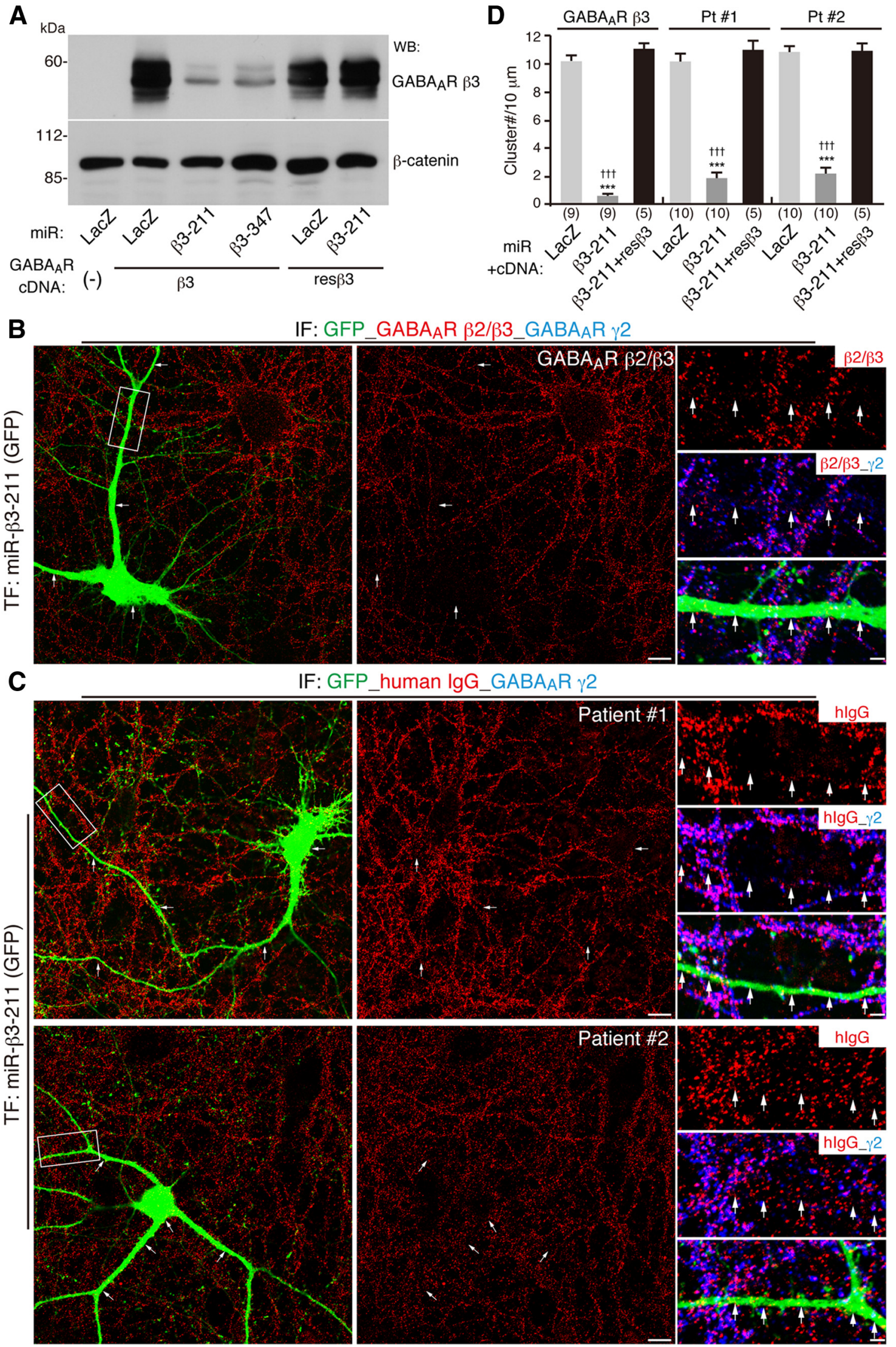

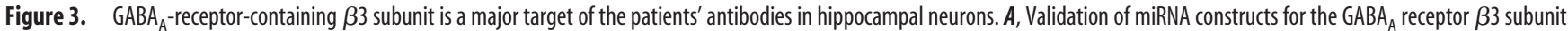
HEK293T cells were cotransfected with the indicated knock-down (miR) and $\beta 3$ expression vectors. Three days after the transfection, the cell lysates were analyzed by Western blotting with GABA receptor $\beta 3$ and $\beta$-catenin antibodies. miR-LacZ, Control miRNA targeting to LacZ; res $\beta 3$, miR-211-resistant $\beta 3$. B, Effective knock down of the endogenous $\beta 3$ subunit. Cultured rat hippocampal neurons were transfected with the miR- $\beta 3$ expression vector at 10 DIV. Cell surface GABA receptor $\beta 2 / \beta 3$ (red) and $\gamma 2$ (blue) subunits were stained at 15 DIV. (Figure legend continues.) 
by anti- $\beta 2 / \beta 3$ antibody was robustly reduced, showing that $\beta 3$ subunit expression was decreased to $5.47 \pm 3.60 \%$ (Fig. $3 B, D$ ). This is consistent with the previous report showing that $\beta 2 \mathrm{ex}-$ pression is very low in hippocampal neurons (Pirker et al., 2000). This reduction was not due to off-target effects of miRNA expression because it was completely rescued by coexpression of the knock-down-resistant $\beta 3$ construct (res $\beta 3$ ) with miRNA- $\beta 3$. We noted that $\gamma 2$ subunit clusters were also decreased in neurons in which the $\beta 3$ subunit was knocked down, confirming an essential role of the $\beta 3$ subunit in the $\mathrm{GABA}_{\mathrm{A}}$ receptor function in hippocampal neurons (DeLorey et al., 1998). Under these conditions, the overall immunoreactivity of the sera from Patient 1 and Patient 2 to the neurons was greatly reduced by the expression of miRNA- $\beta 3-211$ and rescued by coexpression of the knockdown-resistant $\beta 3$ construct. Importantly, the residual immunoreactivity upon $\beta 3$ knock down was $18.2 \pm 10.8 \%$ for Patient 1 and $19.8 \pm 11.7 \%$ for Patient 2 (Fig. $3 C, D$ ). These results indicate that the binding of the patients' antibodies to the neuronal surface was mostly $(\sim 80 \%)$ attributed to the $\mathrm{GABA}_{\mathrm{A}}$ receptor containing the $\beta 3$ subunit and that the patients had other autoantibodies in addition to $\mathrm{GABA}_{\mathrm{A}}$ receptor antibodies.

\section{Coexisting antibodies with $\mathrm{GABA}_{\mathrm{A}}$ receptor antibodies in the patient serum}

We therefore performed the cell-based binding assay (Fig. 4A) and the cell-based ELISA test, which quantifies the frequent serum antibodies against LGI1, CASPR2, DCC (Ohkawa et al., 2013), and $\mathrm{GABA}_{\mathrm{A}}$ receptor $\beta 3$ (Fig. $4 B$ ). We found that the serum samples of Patient 1 and Patient 2, but no other tested serum samples, bound to the $\mathrm{GABA}_{\mathrm{A}}$ receptor $\beta 3$ (Fig. $4 A$ ) and showed similar positive values for $\mathrm{GABA}_{\mathrm{A}}$ receptor antibodies (ELISA absorbance $=0.57$ for Patient $1 ; 0.52$ for Patient 2; Fig. $4 B)$. We also found that Patient 1 had low levels of LGI1 antibodies (absorbance $=0.37$ ) and DCC antibodies (absorbance $=$ 0.26 ) in addition to $\mathrm{GABA}_{\mathrm{A}}$ receptor antibodies, but not CASPR2 antibodies. In contrast, serum from Patient 2 contained CASPR2 antibodies (absorbance $=0.51$ ) and a low level of DCC antibodies (absorbance $=0.21$ ) in addition to $\mathrm{GABA}_{\mathrm{A}}$ receptor antibodies, but not LGI1 antibodies. However, the low level of LGI1 antibodies of Patient 1 is unlikely to cause the patient's CNS symptoms, because the value for LGI1 antibodies of Patient 1 was much lower than the cutoff value (absorbance $=0.8$ ) determined for diagnosis of limbic encephalitis (Ohkawa et al., 2013; see Materials and Methods). In fact, in the present study population, patients with limbic encephalitis and monospecific LGI1 antibodies had much higher levels of LGI1 antibodies (average of ELISA absorbance $=1.41 \pm 0.36, n=34$ patients; Patient $\mathrm{A}$ as a representative) than patients with neuromyotonia (no CNS symptoms) and LGI1 autoantibodies $(0.65 \pm 0.16, n=10$ patients; Patient $\mathrm{C}$ as a representative) (Fig. 4). CASPR2 and DCC antibodies are also unlikely to be causes of the patient's CNS

\footnotetext{
$\leftarrow$

(Figure legend continued.) MicroRNA-transfected neurons were reported by the GFP expression (green). C, Binding of serum antibodies (Patient 1 and Patient 2; red) was examined in neurons in which the $\beta 3$ subunit was knocked down (green). Magnified view of the region indicated by a white square $(\boldsymbol{B}, \boldsymbol{C})$. Arrows indicate the soma and dendrites of the neuron in which $\beta 3$ was knocked down ( $\boldsymbol{B}, \boldsymbol{C})$. Scale bars, $10 \mu \mathrm{m}(2 \mu \mathrm{m}$, magnified). $\boldsymbol{D}$, Neurons were cotransfected with the indicated miR and the knock-down-resistant construct (res $\beta 3$ ) or GST (for mock). The number of clusters labeled by $\beta 3$ antibody or human lgG of patients' serum (Patient 1 and Patient 2) was counted and graphed. One-way ANOVA with Scheffe's post hoc analysis, ${ }^{* * *} p<$ 0.001 compared with miR-LacZ; $+\dagger+p<0.001$ compared with miR- $\beta 3-211+$ res $\beta 3$. Error bars indicate SEM. The number of neurons examined is indicated in parentheses.
}

symptoms because CASPR2 and DCC autoantibodies are specifically associated with PNS symptoms of neuromyotonia, but are not associated with CNS symptoms observed in encephalitis (Ohkawa et al., 2013). Together, these quantitative analyses (Figs. $3,4)$ strongly suggest that the $\mathrm{GABA}_{\mathrm{A}}$ receptor containing the $\beta 3$ subunit is a primary target of the patients' serum antibodies and is the main contributor to the patients' symptoms.

\section{Patients' $\mathrm{GABA}_{\mathrm{A}}$ receptor antibodies reduce the number of both synaptic and surface $\mathrm{GABA}_{\mathrm{A}}$ receptor clusters}

Next, we explored a mode of action of patients' $\mathrm{GABA}_{\mathrm{A}}$ receptor antibodies. Previous studies showed that autoantibodies against NMDA and AMPA receptors induce the internalization of the corresponding receptors and reduce the number of synaptic receptors (Lai et al., 2009; Hughes et al., 2010). These previous findings inspired us to investigate whether patients' $\mathrm{GABA}_{\mathrm{A}}$ receptor antibodies reduce the number of synaptic $\mathrm{GABA}_{\mathrm{A}}$ receptors. When hippocampal neurons were treated with the serum from Patient 1 and Patient 2 for $2 \mathrm{~d}$, the number of synaptic $\mathrm{GABA}_{\mathrm{A}}$ receptor clusters, represented by $\gamma 2$ or $\beta 3$ subunit clusters adjacent to both gephyrin and vGAT, was significantly reduced (Fig. 5A). The effect was specifically attributed to the patients' $\mathrm{GABA}_{\mathrm{A}}$ receptor antibodies because treatment of neurons with a control serum without detectable autoantibodies or with the serum from the patient (Patient C) with invasive thymoma and neuromyotonia, who had LGI1 and CASPR2 antibodies but not $\mathrm{GABA}_{\mathrm{A}}$ receptor antibodies (Fig. 4), did not affect the synaptic $\mathrm{GABA}_{\mathrm{A}}$ receptor clusters. The number of surface $\gamma 2$ subunit clusters, including both synaptic and extrasynaptic $\mathrm{GABA}_{\mathrm{A}}$ receptors, was also heavily reduced by treatment with the serum from Patient 1 and Patient 2. The effect of the patients' serum on $\mathrm{GABA}_{\mathrm{A}}$ receptor clusters was not complement mediated because the heat-inactivated patient serum reduced the number of both synaptic and surface $\mathrm{GABA}_{\mathrm{A}}$ receptor to a similar extent to the nonheat-inactivated patient serum; therefore, we pooled these data. Under these conditions, the number of gephyrin clusters apposed to vGAT was not altered (Fig. 5A). The effect of the patients's sera on $\mathrm{GABA}_{\mathrm{A}}$ receptor clusters was selective because the same treatment did not affect synaptic or surface AMPA receptor subunit GluA1.

This cell biological results were confirmed by the biochemical experiment: hippocampal neurons were treated with the patient or control serum for $3 \mathrm{~d}$ and then the surface-expressed proteins were labeled with biotin and purified by the avidin-conjugated beads (Fig. $5 B$ ). In the patient serum-treated neurons, the amount of cell surface $\mathrm{GABA}_{\mathrm{A}}$ receptor $\beta 3$ subunits was significantly reduced and the total amount of the $\beta 3$ subunit tended to be reduced (but not significantly). This effect was specific to the $\mathrm{GABA}_{\mathrm{A}}$ receptor because the amount of the surface GluA1 and $\mathrm{N}$-cadherin was not affected. Together, these results indicate that $\mathrm{GABA}_{\mathrm{A}}$ receptor autoantibodies cause a selective decrease in $\mathrm{GABA}_{\mathrm{A}}$ receptor surface density and synaptic localization, probably by enhancing the receptor internalization.

To determine the relationship between $\mathrm{GABA}_{\mathrm{A}}$ receptor antibodies and patient' symptoms, we compared serum samples of $\mathrm{Pa}$ tient 1 at two different time points, from the episode of invasive thymoma and myasthenia gravis (without encephalitis) and from the episode of encephalitis. The sample of Patient 1 before the episode of encephalitis had acetylcholine receptor (AchR) antibodies, but no detectable $\mathrm{GABA}_{\mathrm{A}}$ receptor antibodies (Fig. 5 C, Table 1) and showed no effects on synaptic $\mathrm{GABA}_{\mathrm{A}}$ receptor density (Fig. $5 D$ ). In contrast, the sample of the same patient at the time of symptom presentation of encephalitis had elevated $\mathrm{GABA}_{\mathrm{A}}$ receptor antibodies instead of AchR antibodies and decreased synaptic $\mathrm{GABA}_{\mathrm{A}}$ receptor density (Fig. 5C,D). Therefore, the clinical course of Patient 1 
A

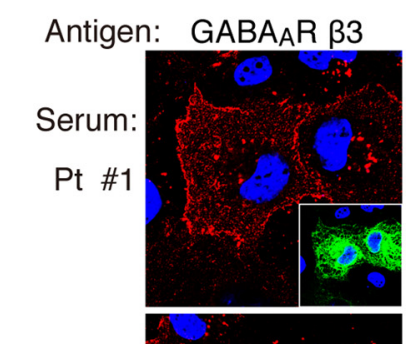

Pt \#2
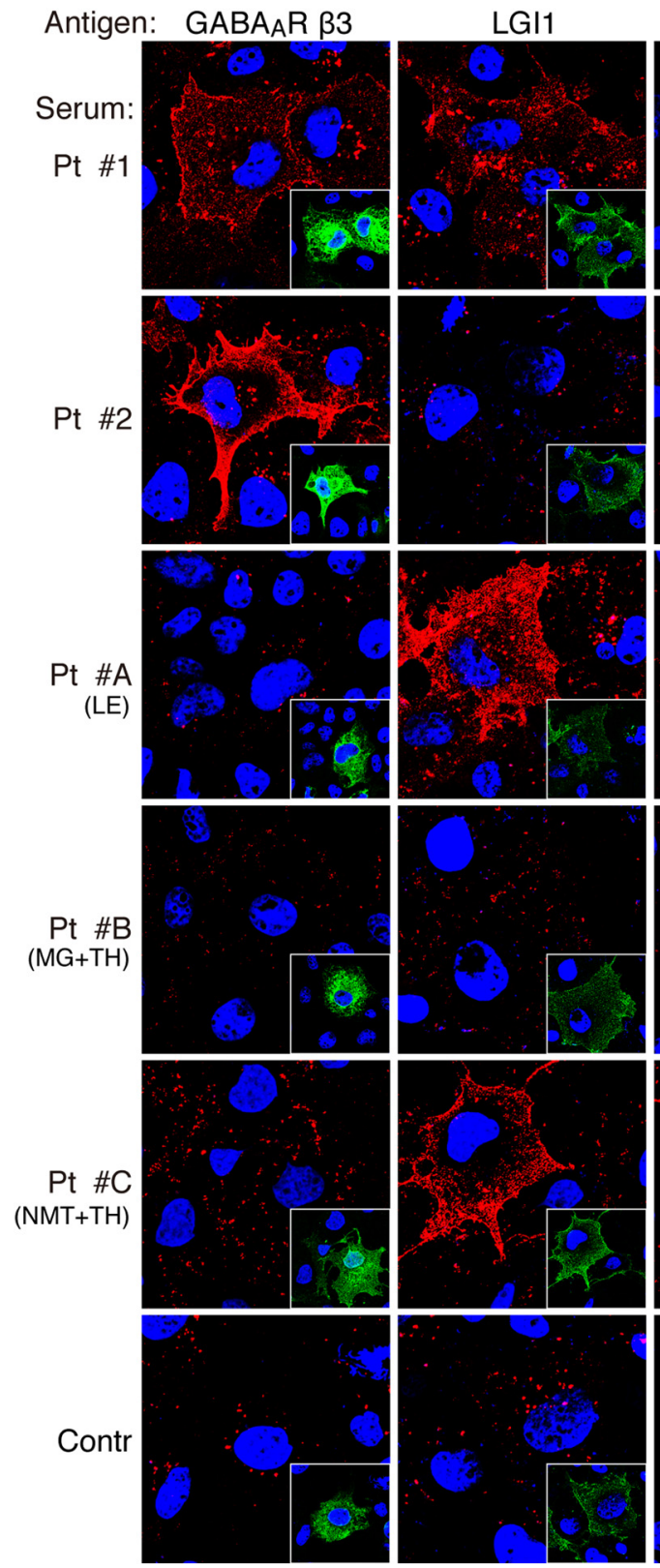

Cell-based binding assay

CASPR2
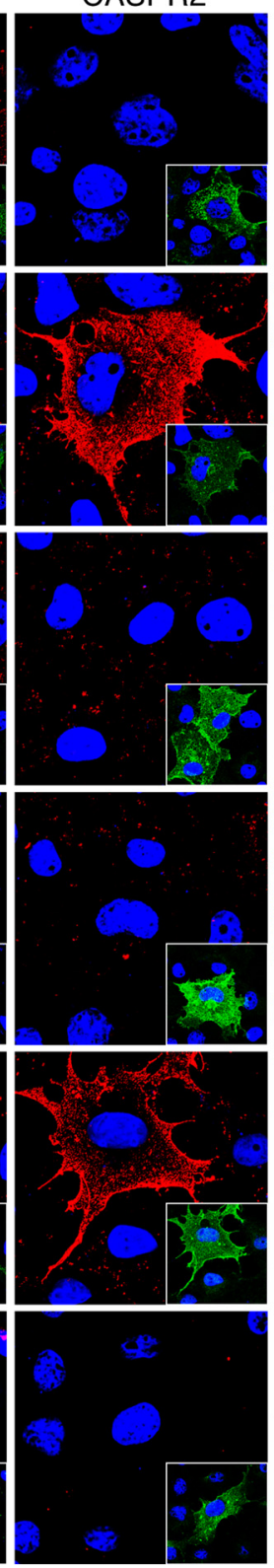

B

Cell-based ELISA
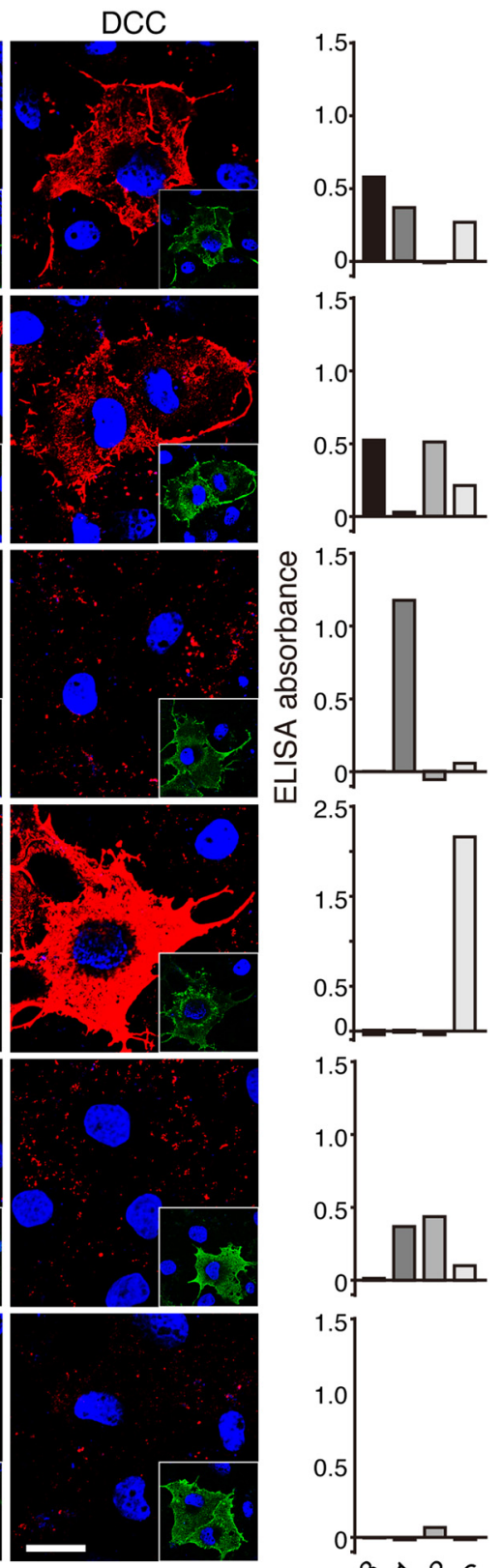

Antigen:
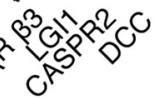

Gr

Figure 4. Identification of coexisting antibodies with $G A B A_{A}$ receptor antibodies in the patient serum. $A, B$, Patient 1 and Patient 2 sera from their initial episodes of encephalitis were tested by cell-based binding assay $(\boldsymbol{A})$ and cell-based ELISA tests $(\boldsymbol{B})$ against the GABA $A_{A}$ receptor $\beta 3$ subunit, LGI1, CASPR2, and DCC. Additional sera were tested: from Patient $A$ with limbic encephalitis (LE), Patient B with myasthenia gravis (MG) and thymoma (TH), and Patient C with neuromyotonia (NMT) and thymoma. Contr, Serum sample from a control patient with a neurodegenerative disease. Scale bar, $20 \mu \mathrm{m}$ in $\boldsymbol{A}$. Average values from triplicate measurements of the individual serum are shown in $\boldsymbol{B}$.

correlates with the levels and effects of the patient's $\mathrm{GABA}_{\mathrm{A}}$ receptor antibodies. Although LGI1 antibodies were also detected only at the time of symptom presentation of encephalitis, the low level of LGI1 antibodies is unlikely to cause the patient's CNS symptoms, as described for Figure 4 (also see Discussion).

Patients' $\mathrm{GABA}_{\mathrm{A}}$ receptor antibodies selectively reduce mIPSC amplitude and frequency

Finally, we assessed the effects of two patient sera (Patient 1 and Patient 2) on inhibitory synaptic transmission by whole-cell patch-clamp recording of mIPSCs in rat hippocampal neurons. We found a significant decrease in the mean amplitude of mIPSCs in patients' serum-treated neurons compared with that of control serum-treated neurons (Fig. $6 A, B$ ). This result is consistent with our immunocytochemical data (Fig. 5A) showing that the treatment of neurons with patients' serum reduced the number of synaptic clusters of $\mathrm{GABA}_{\mathrm{A}}$ receptors. The frequency of mIPSCs was also decreased in patients' serumtreated neurons (Fig. $6 A, B$ ), probably due to the increase in small-amplitude mIPSCs that fell below the threshold of de- 

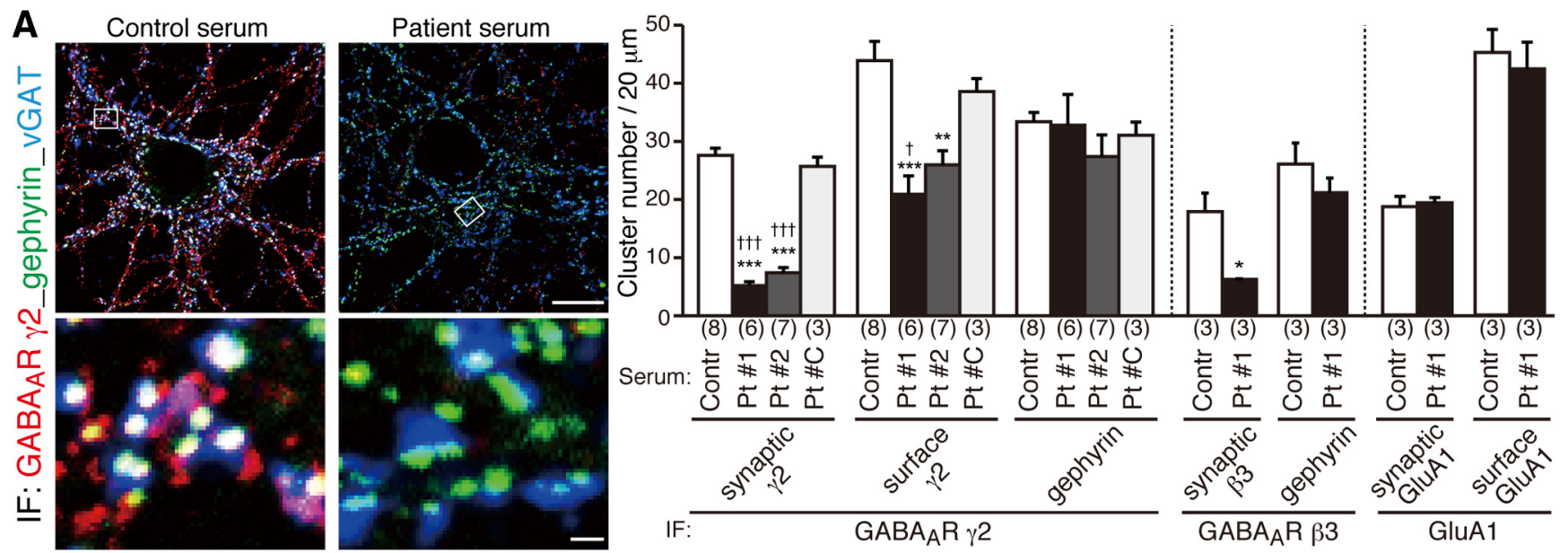

B
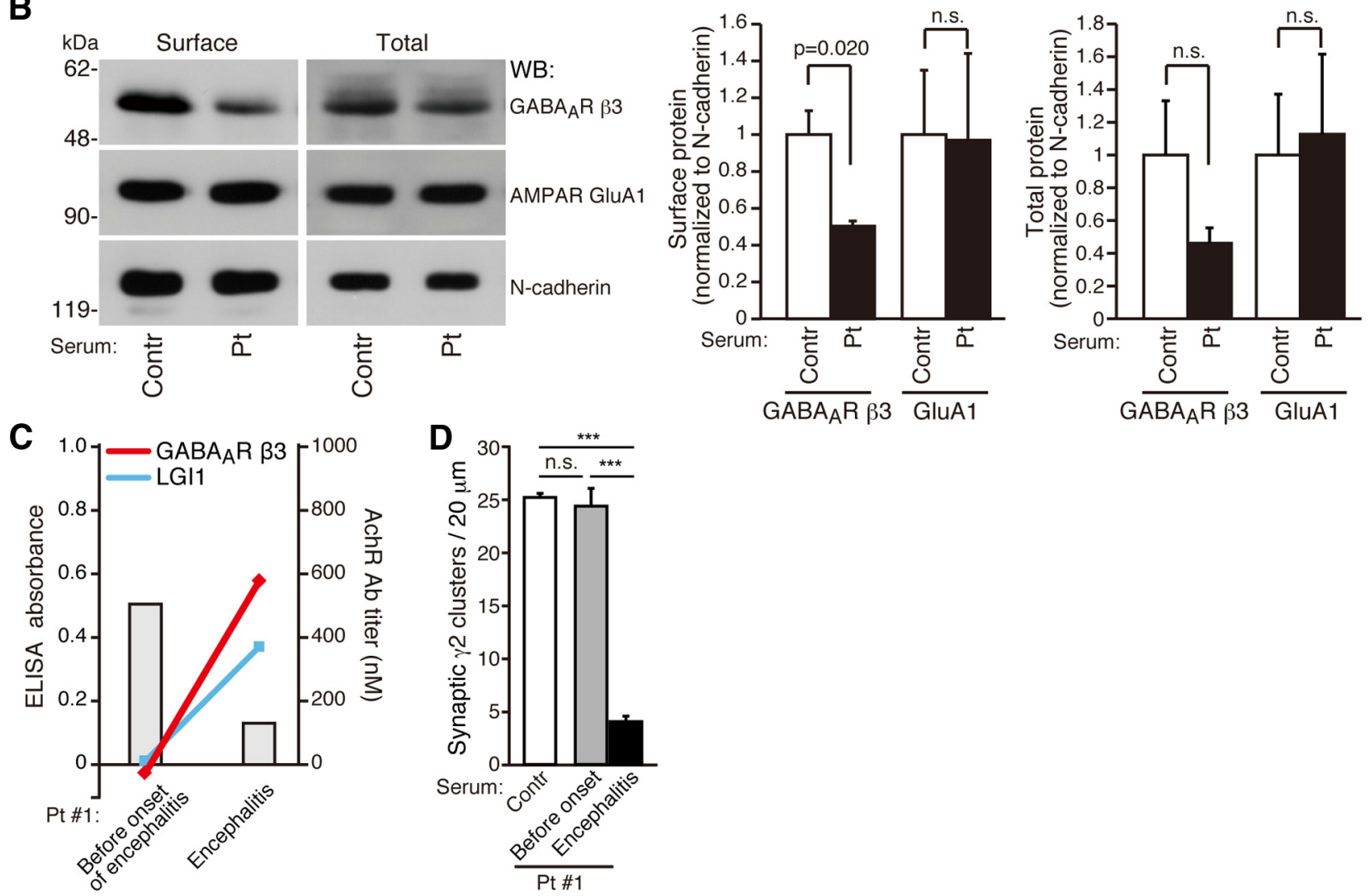

Figure 5. Patients' $G A B A_{A}$ receptor antibodies specifically reduce synaptic and cell surface $G A B A_{A}$ receptor density. $A$, Cultured rat hippocampal neurons were incubated with serum from Patient 1 and Patient 2, serum from Patient ( with thymoma that contained both LGI1 and CASPR2 antibodies (Fig. 4), or a control serum for 2 d. Representative images of surface GABA $_{A}$ receptor clusters in neurons treated with the control or the serum from Patient 1 are shown (left). Bottom, Magnified view of the region indicated by a white square. Synaptic GABA receptors, which were $\gamma 2$ (red) or $\beta 3$ (data not shown) subunit-positive clusters adjacent to both gephyrin (green) and vGAT (blue), were counted. Surface-expressed GABA $A_{A}$ receptor clusters labeled by the $\gamma 2$ subunit antibody and gephyrin clusters were also independently counted. In addition, synaptic GluA1 clusters adjacent to both PSD-95 and vGluT1 and surface-expressed GluA1 clusters were counted. Scale bars, 20 $\mu \mathrm{m}\left(1 \mu \mathrm{m}\right.$, magnified). Statistical analyses were performed by one-way ANOVA with Scheffe's post hoc analysis ( $\gamma 2$ clusters); or by Student's $t$ test $\left(\beta 3\right.$ and GluA1 clusters). ${ }^{*} p<0.05$; ${ }^{* *} p<0.01$; ${ }^{* * *} p<0.001$ compared with control; $\uparrow p<0.05,+\dagger \dagger p<0.001$ compared with Patient C. Error bars indicate SEM. The number of separate cultures is indicated in parentheses. B, Surface biotinylated and total proteins of the serum from Patient 1 treated hippocampal neurons were analyzed by Western blotting with the indicated antibodies. Student's $t$ test; n.s., not significant. Error bars indicate SEM; $n=3$ separate cultures. C, $D$, Serum samples of Patient 1 at two different time points, from the episode of thymoma and MG (before onset of encephalitis) and from the episode of encephalitis, were analyzed by cell-based ELISA ( $\boldsymbol{C}$, and their effects on synaptic GABA receptors were investigated (D). Average values for GABA $A_{A}$ receptor $\beta 3$ and LGI1 ELISA from triplicate

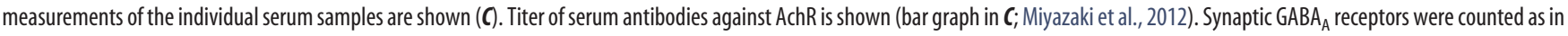
A. One-way ANOVA with Tukey's post hoc analysis; ${ }^{* * *} p<0.001$; n.s., not significant. Error bars indicate SEM; $n=3$ separate cultures.

tection. In support of this, cumulative distribution of the mIPSC amplitude of the patients' serum-treated neurons showed the significant leftward shift (Fig. 6C). In contrast, patients' antibodies did not affect AMPA-receptor-mediated
mEPSCs (Fig. 6A,D), which is also consistent with no effects of the patients' antibodies on synaptic AMPA receptor clusters (Fig. $5 A)$. Therefore, patients' antibodies specifically reduce the synaptic $\mathrm{GABA}_{\mathrm{A}}$ receptor function. 
A
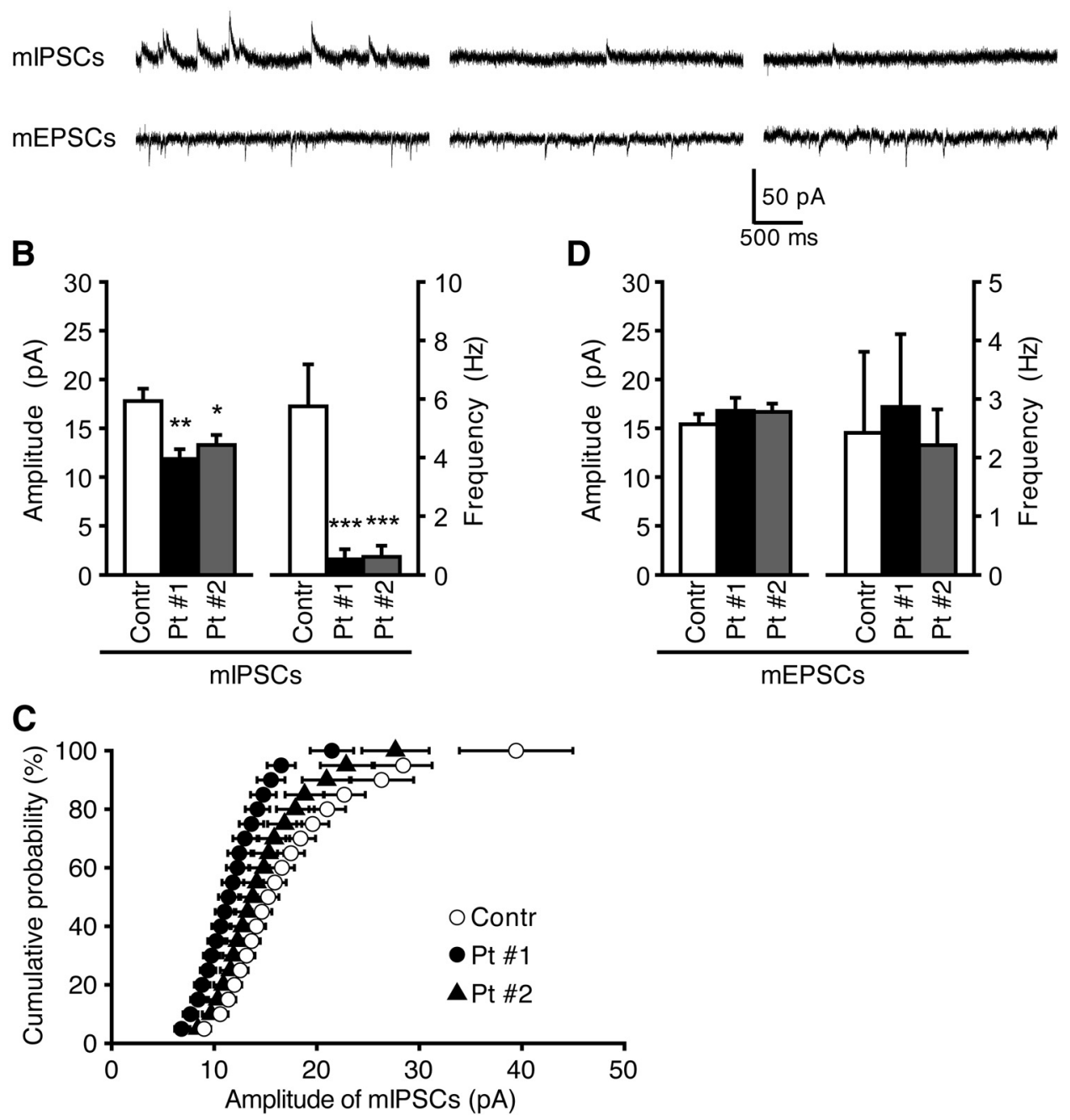

Figure 6. Patients' $G_{A B A}$ receptor antibodies selectively decrease mIPSCS. $A$, Representative traces of $\mathrm{mIPSCs}\left(V_{H}=-20 \mathrm{mV}\right.$, top $)$ and $\mathrm{mEPSCs}\left(V_{H}=-80 \mathrm{mV}\right.$, bottom $)$ recorded from cultured rat hippocampal neurons, which were incubated with the serum from Patient 1 and Patient 2 or a control individual for $1 \mathrm{~d}$. $\boldsymbol{B}, \boldsymbol{D}$, Treatment of neurons with the patient serum significantly decreased the amplitude and frequency in $\mathrm{mIPSCS}(\boldsymbol{B})$, but did not affect those in mEPSCS $(\boldsymbol{D})$. Statistical analyses were performed by one-way ANOVA with Scheffe's post hoc analysis. ${ }^{*} p<0.05$; ${ }^{* *} p<0.01$; ${ }^{* * *} p<0.001$ compared with control. C, Cumulative distribution of the mIPSC amplitude. Note the significant leftward shift in the amplitude distribution in the patients' serum-treated neurons $\left(F_{(2,540)}=62.9, p<0.001\right.$; two-way ANOVA). Error bars indicate SEM; Control, $n=9 ;$ Patient $1, n=10 ;$ Patient $2, n=11$ (B, C); Control, $n=9 ;$ Patient 1, $n=9$; Patient 2, $n=12$ (D). $n$ values indicate the number of neurons examined from two separate cultures.

\section{Discussion}

Identification of $\mathrm{GABA}_{\mathrm{A}}$ receptor autoantibodies in autoimmune encephalitis

GABA is a major inhibitory neurotransmitter and exerts its functions through ionotropic $\mathrm{GABA}_{\mathrm{A}}$ receptors and metabotropic $\mathrm{GABA}_{\mathrm{B}}$ receptors. $\mathrm{GABA}_{\mathrm{B}}$ receptor was recently identified as an autoantigen associated with limbic encephalitis (Lancaster et al., 2010). However, antibodies to the ionotropic $\mathrm{GABA}_{\mathrm{A}}$ receptor have not been yet reported in any neuroimmunological disorders. Here, we found the autoantibodies to $\mathrm{GABA}_{\mathrm{A}}$ receptors in patients with autoimmune encephalitis and revealed a mode of action of the antibodies. One may wonder why $\mathrm{GABA}_{\mathrm{A}}$ receptor autoantibodies have not been found for a long time. One possibility is that the immunoprecipitated band of human IgG (heavy chains) almost completely overlaps with bands of co-isolated $\mathrm{GABA}_{\mathrm{A}}$ receptor subunits (all are $\sim 50 \mathrm{kDa}$ ) in the SDS-PAGE gel, thereby hindering the detection of $\mathrm{GABA}_{\mathrm{A}}$ receptor subunits. Very recently, while this manuscript was under review, a related paper was published reporting the identification of $\mathrm{GABA}_{\mathrm{A}}$ re- ceptor autoantibodies in patients with encephalitis showing refractory seizures and/or status epilepticus (Petit-Pedrol et al., 2014). Their history of autoimmunity or cancer seems different from that of our cases. In cases they reported, autoantibodies to $\mathrm{GABA}_{\mathrm{A}}$ receptors were sometimes concurrently detected with autoantibodies to GAD65 or $\mathrm{GABA}_{\mathrm{B}}$ receptor and were not frequently associated with underlying tumors. In contrast, our cases represent a paraneoplastic subtype of encephalitis with invasive thymoma (Table 1) in which $\mathrm{GABA}_{\mathrm{A}}$ receptor autoantibodies coexist with LGI1, CASPR2, or DCC antibodies. It will be worthwhile to test patients presenting with thymoma and encephalitis for $\mathrm{GABA}_{\mathrm{A}}$ receptor autoantibodies.

\section{Link between $\mathrm{GABA}_{\mathrm{A}}$ receptor autoantibodies and} patient symptoms

We found that the $\mathrm{GABA}_{\mathrm{A}}$ receptor antibodies of both Patient 1 and Patient 2 targeted the $\beta 3$ subunit of the $\mathrm{GABA}_{\mathrm{A}}$ receptor directly. Based on the previous genetic studies showing that mutations in the human $\mathrm{GABA}_{\mathrm{A}}$ receptor $\beta 3$ subunit cause genetic 
epilepsy syndromes (Macdonald et al., 2010) and that the genetic loss of the $\beta 3$ subunit causes seizures and learning and memory deficits in mice (DeLorey et al., 1998), it is strongly suggested that the patients' $\mathrm{GABA}_{\mathrm{A}}$ receptor antibodies are the direct cause of some CNS disorders such as cognitive impairment and/or seizures often observed in encephalitis. Consistently, both the patients' antibodies similarly showed a selective effect on inhibitory synapses (Figs. 5, 6). In addition, only the serum sample from the episode of encephalitis (Patient 1) had decreased synaptic $\mathrm{GABA}_{\mathrm{A}}$ receptor density, whereas the sample of the same patient before the onset of encephalitis had no detectable $\mathrm{GABA}_{\mathrm{A}}$ receptor antibodies and no effects on synaptic $\mathrm{GABA}_{\mathrm{A}}$ receptor density (Fig. $5 C, D$ ). To further strengthen the link between $\mathrm{GABA}_{\mathrm{A}}$ receptor antibodies and patients' symptoms, we considered two additional factors of two patients, "thymoma" and "VGKCcomplex antibodies," as follows.

The Patient 1 and Patient 2 both had invasive thymoma (Table 1) (Ohshita et al., 2006; Miyazaki et al., 2012). Because patients with (invasive) thymoma often develop multiple autoantibodies due to disturbed self-tolerance, we included patients with thymoma as controls. Our subjects for the screening contained 19 patients with thymoma, but only two patients had $\mathrm{GABA}_{\mathrm{A}}$ receptor antibodies, indicating that not all patients with thymoma develop $\mathrm{GABA}_{\mathrm{A}}$ receptor antibodies. For example, the Patient B, with invasive thymoma and myasthenia gravis, had monospecifically DCC antibodies without $\mathrm{GABA}_{\mathrm{A}}$ receptor antibodies, whereas Patient $\mathrm{C}$, with invasive thymoma and neuromyotonia, had LGI1 and CASPR2 antibodies without $\mathrm{GABA}_{\mathrm{A}}$ receptor antibodies (Fig. 4). Treatment of hippocampal neurons with these patients' serum did not affect synaptic $\mathrm{GABA}_{\mathrm{A}}$ receptor clusters (Fig. $5 \mathrm{~A}$ for Patient C; cluster number for Patient $\mathrm{B}$ serum, $25.0 \pm$ $4.5 / 20 \mu \mathrm{m}$ dendrite and control serum, $25.4 \pm 4.2, p=0.85$, Student's $t$ test; $n=11$ neurons).

In addition, we included patients with VGKC-complex antibodies as controls because Patient 1 and Patient 2 both had VGKCcomplex antibodies (649 pM for Patient 1; 403 pM for Patient 2; Table 1), which are now attributed to LGI1 and/or CASPR2 antibodies, and previous case reports for these patients showed a correlation between patients' symptoms and the follow-up of VGKC-complex antibodies (Ohshita et al., 2006; Miyazaki et al., 2012). Here, we investigated the serum from Patient $\mathrm{C}$ as a control because the patient had VGKC-complex antibodies (809 pM; now revealed as LGI1 and CASPR2 antibodies; Fig. 4) but no $\mathrm{GABA}_{\mathrm{A}}$ receptor antibodies. Treatment with this patient serum did not affect the synaptic $\mathrm{GABA}_{\mathrm{A}}$ receptor clusters (Fig. 5A). In addition, we tested another patient serum with VGKC-complex antibodies (2121 pM) and limbic encephalitis. The patient had high level of monospecific LGI1 antibodies (absorbance $=1.86$ ) without $\mathrm{GABA}_{\mathrm{A}}$ receptor antibodies. This serum treatment did not affect the synaptic $\mathrm{GABA}_{\mathrm{A}}$ receptor clusters (cluster number for control serum, 27.6 \pm 1.2 ; for the patient serum, $24.6 \pm 2.3, p=0.39$, Student's $t$ test; $n=3$ separate cultures). These overall results exclude the possibility that coexisting antibodies other than $\mathrm{GABA}_{\mathrm{A}}$ receptor antibodies mediate the effects and support the specific role of $\mathrm{GABA}_{\mathrm{A}}$ receptor antibodies in the patients' symptoms.

Two patients with $\mathrm{GABA}_{\mathrm{A}}$ receptor antibodies shared some clinical features: cognitive impairment, multifocal abnormal brain MRI signals, and invasive thymoma (Table 1). Importantly, Patient 1 had seizures/status epilepticus, but Patient 2 had no seizure episodes. Given that loss of the $\beta 3$ subunit in mice causes seizures and learning and memory deficits (DeLorey et al., 1998), it is reasonable to expect that loss of function of the $\mathrm{GABA}_{\mathrm{A}}$ receptor mediated by $\mathrm{GABA}_{\mathrm{A}}$ receptor $\beta 3$ antibodies may cause seizures in human patients. However, at present, it seems too early to conclude that $\mathrm{GABA}_{\mathrm{A}}$ receptor antibodies should always cause seizures in human patients. It is conceivable that the brain regions where the antibodies act and the amount of the antibodies at different regions can be highly variable between patients. In addition, other factors such as medication and coexisting antibodies may modify the clinical features. In fact, Patient 2 had suffered from postherpetic neuralgia and had been under treatment with carbamazepine, an antiepileptic and anti-nerve-pain drug, for 5 years, including the periods of the initial episode and the relapse of encephalitis (Ohshita et al., 2006) (Table 1). This medication might have prevented the patient's seizure onset. The exact relationship between $\mathrm{GABA}_{\mathrm{A}}$ receptor antibodies and specific CNS symptoms will be clarified in the future as the number of cases increases.

\section{Anti-GABA $\mathrm{A}$ receptor encephalitis as a new class of autoimmune encephalitis}

The present study indicates that encephalitis associated with $\mathrm{GABA}_{\mathrm{A}}$ receptor antibodies shows different clinical features and mechanisms, at least from limbic encephalitis associated with monospecific LGI1 antibodies. Both cases with the $\mathrm{GABA}_{\mathrm{A}}$ receptor antibodies showed the similar brain MRI finding, extensive multifocal lesions involving bilateral temporal lobes (Ohshita et al., 2006; Miyazaki et al., 2012). In contrast, limbic encephalitis with LGI1 autoantibodies is featured by the typical MRI finding with the focal lesion of medial temporal lobes (Cash et al., 2011; Lancaster et al., 2011). We previously found that the monospecific serum against LGI1 (ELISA absorbance $=1.86)$ from a patient with limbic encephalitis significantly reduce synaptic AMPA receptor density of hippocampal neurons (Ohkawa et al., 2013), but the serum did not affect synaptic $\mathrm{GABA}_{\mathrm{A}}$ receptor density. Conversely, serum from Patient 1 showed a selective effect on $\mathrm{GABA}_{\mathrm{A}}$ receptor function, but did not affect synaptic AMPA receptor density nor mEPSCs regardless of coexisting LGI1 antibodies (absorbance $=0.37$; Figs. 5A, 6). Unlike NMDA, AMPA, and $\mathrm{GABA}_{\mathrm{A}}$ receptor antibodies directly targeting ionotropic receptors to induce the receptor internalization (Lai et al., 2009; Hughes et al., 2010; Fig. 5), LGI1 antibodies need to titrate out endogenous LGI1 to prevent LGI1 from binding to its receptor ADAM22 and then to reduce synaptic AMPA receptors. This indirect mode of action of LGI1 antibodies should require a higher concentration of LGI1 antibodies to be effective. Therefore, the loss of effect of serum from Patient 1 on synaptic AMPA receptors is probably due to the low LGI1 antibody level (Fig. $4 B$ ) and in turn highlights a predominant role of the $\mathrm{GABA}_{\mathrm{A}}$ receptor antibodies in the symptoms experienced by Patient 1 . Therefore, it is conceivable that encephalitis with $\mathrm{GABA}_{\mathrm{A}}$ receptor antibodies might be distinguished as a new class of autoimmune encephalitis. In addition, we propose that clinical phenotypes of autoimmune anti-GABA $A_{\mathrm{A}}$ receptor encephalitis may be further modified by the combination of coexisting autoantibodies such as LGI1, CASPR2, or DCC antibodies, especially if the patient has thymoma. The multiplex ELISA testing to determine the involved autoantibodies will be essential for the accurate diagnosis of a spectrum of autoimmune encephalitis.

In conclusion, we discovered $\mathrm{GABA}_{\mathrm{A}}$ receptor autoantibodies associated with autoimmune encephalitis and revealed their pathogenic role, downregulation of the $\mathrm{GABA}_{\mathrm{A}}$ receptor function. Given that many agonistic and antagonistic ligands bind to specific sites on the $\mathrm{GABA}_{\mathrm{A}}$ receptor, the fine epitope mapping of autoantibodies on the $\mathrm{GABA}_{\mathrm{A}}$ receptor $\beta 3$ subunit may contribute to further understanding the pathogenic mechanism causing 
abnormal neuronal excitation in the brain and developing therapeutic interventions.

\section{References}

Cash SS, Larvie M, Dalmau J (2011) Case records of the Massachusetts General Hospital. Case 34-2011: A 75-year-old man with memory loss and partial seizures. N Engl J Med 365:1825-1833. CrossRef Medline

Dalmau J, Tüzün E, Wu HY, Masjuan J, Rossi JE, Voloschin A, Baehring JM, Shimazaki H, Koide R, King D, Mason W, Sansing LH, Dichter MA, Rosenfeld MR, Lynch DR (2007) Paraneoplastic anti-N-methyl-Daspartate receptor encephalitis associated with ovarian teratoma. Ann Neurol 61:25-36. CrossRef Medline

Dalmau J, Gleichman AJ, Hughes EG, Rossi JE, Peng X, Lai M, Dessain SK, Rosenfeld MR, Balice-Gordon R, Lynch DR (2008) Anti-NMDAreceptor encephalitis: case series and analysis of the effects of antibodies. Lancet Neurol 7:1091-1098. CrossRef Medline

DeLorey TM, Handforth A, Anagnostaras SG, Homanics GE, Minassian BA, Asatourian A, Fanselow MS, Delgado-Escueta A, Ellison GD, Olsen RW (1998) Mice lacking the beta3 subunit of the $\mathrm{GABA}_{\mathrm{A}}$ receptor have the epilepsy phenotype and many of the behavioral characteristics of Angelman syndrome. J Neurosci 18:8505-8514. Medline

Fang C, Deng L, Keller CA, Fukata M, Fukata Y, Chen G, Lüscher B (2006) GODZ-mediated palmitoylation of $\mathrm{GABA}_{\mathrm{A}}$ receptors is required for normal assembly and function of GABAergic inhibitory synapses. J Neurosci 26:12758-12768. CrossRef Medline

Fukata Y, Lovero KL, Iwanaga T, Watanabe A, Yokoi N, Tabuchi K, Shigemoto R, Nicoll RA, Fukata M (2010) Disruption of LGI1-linked synaptic complex causes abnormal synaptic transmission and epilepsy. Proc Natl Acad Sci U S A 107:3799-3804. CrossRef Medline

Fukata Y, Dimitrov A, Boncompain G, Vielemeyer O, Perez F, Fukata M (2013) Local palmitoylation cycles define activity-regulated postsynaptic subdomains. J Cell Biol 202:145-161. CrossRef Medline

Hughes EG, Peng X, Gleichman AJ, Lai M, Zhou L, Tsou R, Parsons TD, Lynch DR, Dalmau J, Balice-Gordon RJ (2010) Cellular and synaptic mechanisms of anti-NMDA receptor encephalitis. J Neurosci 30:58665875. CrossRef Medline

Hutchinson M, Waters P, McHugh J, Gorman G, O'Riordan S, Connolly S, Hager H, Yu P, Becker CM, Vincent A (2008) Progressive encephalomyelitis, rigidity, and myoclonus: a novel glycine receptor antibody. Neurology 71:1291-1292. CrossRef Medline

Irani SR, Alexander S, Waters P, Kleopa KA, Pettingill P, Zuliani L, Peles E, Buckley C, Lang B, Vincent A (2010) Antibodies to Kv1 potassium channel-complex proteins leucine-rich, glioma inactivated 1 protein and contactin-associated protein-2 in limbic encephalitis, Morvan's syndrome and acquired neuromyotonia. Brain 133:2734-2748. CrossRef Medline

Jacob TC, Moss SJ, Jurd R (2008) GABA A receptor trafficking and its role in the dynamic modulation of neuronal inhibition. Nat Rev Neurosci 9:331343. CrossRef Medline

Lai M, Hughes EG, Peng X, Zhou L, Gleichman AJ, Shu H, Matà S, Kremens D, Vitaliani R, Geschwind MD, Bataller L, Kalb RG, Davis R, Graus F, Lynch DR, Balice-Gordon R, Dalmau J (2009) AMPA receptor antibodies in limbic encephalitis alter synaptic receptor location. Ann Neurol 65:424-434. CrossRef Medline

Lai M, Huijbers MG, Lancaster E, Graus F, Bataller L, Balice-Gordon R, Cowell JK, Dalmau J (2010) Investigation of LGIl as the antigen in limbic encephalitis previously attributed to potassium channels: a case series. Lancet Neurol 9:776-785. CrossRef Medline

Lancaster E, Dalmau J (2012) Neuronal autoantigens-pathogenesis, associated disorders and antibody testing. Nat Rev Neurol 8:380-390. CrossRef Medline

Lancaster E, Lai M, Peng X, Hughes E, Constantinescu R, Raizer J, Friedman
D, Skeen MB, Grisold W, Kimura A, Ohta K, Iizuka T, Guzman M, Graus F, Moss SJ, Balice-Gordon R, Dalmau J (2010) Antibodies to the GABA receptor in limbic encephalitis with seizures: case series and characterisation of the antigen. Lancet Neurol 9:67-76. CrossRef Medline

Lancaster E, Martinez-Hernandez E, Dalmau J (2011) Encephalitis and antibodies to synaptic and neuronal cell surface proteins. Neurology 77: 179-189. CrossRef Medline

Macdonald RL, Olsen RW (1994) $\mathrm{GABA}_{\mathrm{A}}$ receptor channels. Annu Rev Neurosci 17:569-602. CrossRef Medline

Macdonald RL, Kang JQ, Gallagher MJ (2010) Mutations in $\mathrm{GABA}_{\mathrm{A}}$ receptor subunits associated with genetic epilepsies. J Physiol 588:1861-1869. CrossRef Medline

McKeon A, Martinez-Hernandez E, Lancaster E, Matsumoto JY, Harvey RJ, McEvoy KM, Pittock SJ, Lennon VA, Dalmau J (2013) Glycine receptor autoimmune spectrum with stiff-man syndrome phenotype. JAMA Neurol 70:44-50. CrossRef Medline

Miyazaki Y, Hirayama M, Watanabe H, Usami N, Yokoi K, Watanabe O, Sobue G (2012) Paraneoplastic encephalitis associated with myasthenia gravis and malignant thymoma. J Clin Neurosci 19:336-338. CrossRef Medline

Moscato EH, Jain A, Peng X, Hughes EG, Dalmau J, Balice-Gordon RJ (2010) Mechanisms underlying autoimmune synaptic encephalitis leading to disorders of memory, behavior and cognition: insights from molecular, cellular and synaptic studies. Eur J Neurosci 32:298-309. CrossRef Medline

Ohkawa T, Fukata Y, Yamasaki M, Miyazaki T, Yokoi N, Takashima H, Watanabe M, Watanabe O, Fukata M (2013) Autoantibodies to epilepsyrelated LGI1 in limbic encephalitis neutralize LGI1-ADAM22 interaction and reduce synaptic AMPA receptors. J Neurosci 33:18161-18174. CrossRef Medline

Ohshita T, Kawakami H, Maruyama H, Kohriyama T, Arimura K, Matsumoto M (2006) Voltage-gated potassium channel antibodies associated limbic encephalitis in a patient with invasive thymoma. J Neurol Sci 250 : 167-169. CrossRef Medline

Petit-Pedrol M, Armangue T, Peng X, Bataller L, Cellucci T, Davis R, McCracken L, Martinez-Hernandez E, Mason WP, Kruer MC, Ritacco DG, Grisold W, Meaney BF, Alcalá C, Sillevis-Smitt P, Titulaer MJ, BaliceGordon R, Graus F, Dalmau J (2014) Encephalitis with refractory seizures, status epilepticus, and antibodies to the $\mathrm{GABA}_{\mathrm{A}}$ receptor: a case series, characterisation of the antigen, and analysis of the eff ects of antibodies. Lancet Neurol 13:276-286. CrossRef Medline

Pirker S, Schwarzer C, Wieselthaler A, Sieghart W, Sperk G (2000) GABA receptors: immunocytochemical distribution of 13 subunits in the adult rat brain. Neuroscience 101:815-850. CrossRef Medline

Rudolph U, Knoflach F (2011) Beyond classical benzodiazepines: novel therapeutic potential of $\mathrm{GABA}_{\mathrm{A}}$ receptor subtypes. Nat Rev Drug Discov 10:685-697. CrossRef Medline

Satake S, Imoto K (2014) $\mathrm{Ca}_{\mathrm{v}} 2.1$ channels control multivesicular release by relying on their distance from exocytotic $\mathrm{Ca}^{2+}$ sensors at rat cerebellar granule cells. J Neurosci 34:1462-1474. CrossRef Medline

Satake S, Saitow F, Rusakov D, Konishi S (2004) AMPA receptor-mediated presynaptic inhibition at cerebellar GABAergic synapses: a characterization of molecular mechanisms. Eur J Neurosci 19:2464-2474. CrossRef Medline

Sillevis Smitt P, Kinoshita A, De Leeuw B, Moll W, Coesmans M, Jaarsma D, Henzen-Logmans S, Vecht C, De Zeeuw C, Sekiyama N, Nakanishi S, Shigemoto R (2000) Paraneoplastic cerebellar ataxia due to autoantibodies against a glutamate receptor. N Engl J Med 342:21-27. CrossRef Medline

Vincent A, Lang B, Kleopa KA (2006) Autoimmune channelopathies and related neurological disorders. Neuron 52:123-138. CrossRef Medline 